\title{
EXPLOATAREA MAMIFERELOR DIN NIVELUL BOIAN SPANȚOV DIN TELL-UL DE LA HÂRŞOVA (SECȚIUNEA C)
}

ADRIAN BĂLĂȘESCU

\section{REZUMAT:}

Studiul arheozoologic al faunei de mamifere din nivelul Boian Spanțov descoperit în secțiunea C a tell-ului de la Hârșova ne relevă că această populație preistorică se ocupa cu creșterea animalelor, în special a bovinelor și a ovicaprinelor. Vârstele de sacrificare în cazul bovinelor ilustrează o exploatare mixtă (atât pentru carne, cât și pentru producția de lapte), în timp ce ovicaprinele erau crescute mai ales pentru producția de lapte. Porcul este exploatat prin excelență pentru carne și grăsime, iar studiul vârstelor de abataj ne arată consumul unei cărni de foarte bună calitate dat fiind că cele mai multe animale au sub 12 luni, ele neatingând încă maximul ponderal. Câinele are și o funcție alimentară, pe lângă cea de paznic al turmelor, locuințelor și companion al omului, dar importanța sa în cadrul paleoeconomiei animaliere nu este atât de mare având în vedere talia sa modestă. Vânătoarea avea un rol secundar de suplimentare a cantității de carne, dar și de îndepărtare a acțiunii prădătoare a unor animale sălbatice. Se vânau în special mistrețul și cerbul.

O comparație cu alte situri Boian Spanțov care au beneficiat de studii arheozoologice (Căscioarele, Izvoarele, Lăceni-Măgura, Radovanu, Tangâru) ne arată că o trăsătură comună a acestora o reprezintă activitatea de creștere a bovinelor. Locul secund este disputat între ovicaprine și porcine care se găsesc la mare distanță de bovine. Vânătoarea are o importanță redusă, locul întâi fiind ocupat de cerb în majoritatea așezărilor, mai puțin la Hârșovatell unde se observă că mistrețul are o pondere relativ crescută.

\section{RÉSUMÉ: EXPloitation de MAMMIFÈres du NIVEAU Boian SPANȚOV DE HÂRŞOVA TELL (SECTION C)}

L'étude archéozoologique de la faune mammifère (mammalienne) du niveau Boian Spanțov fouillé dans la section $\mathrm{C}$ du tell de Hârșova montre que cette population préhistorique pratiquait l'élevage, en particulier de bovins et de caprinés. Les âges d'abattage des bovins illustrent une exploitation mixte (tant pour la production de viande que du lait), tandis que les caprinés étaient principalement exploités pour la production de lait. Les porcins sont élevés essentiellement pour la viande et la graisse, et l'étude des âges d'abattage montre la consommation d'une viande de très bonne qualité, puisque la plupart des animaux sont âgés de moins de 12 mois, n'atteignant pas encore leur poids maximum. Le chien a également une fonction alimentaire, outre sa fonction de gardien de troupeaux et des maisons, animal de compagnie de l'homme. Son importance dans la paléo-diète n'est toutefois pas importante compte tenu de sa taille modeste. La chasse avait un rôle secondaire en accroissant la quantité de viande, mais également en supprimant l'action prédatrice de certains animaux sauvages, en particulier le sanglier et le cerf.

Une comparaison avec d'autres ensembles archéozoologiques contemporains de la culture Boian Spanţov (Căscioarele, Izvoarele, Lăceni-Măgura, Radovanu, Tangâru) montre une tendance comparable avec le tell de Hârşova, comme l'élevage de bovins, alors que les caprinés et les porcins sont relégués à la seconde place. La chasse est d'une importance mineure, avec au premier rang le cerf dans la plupart des établissements. La chasse au sanglier semble être une spécificité du tell de Hârșova.

CUVINTE CHEIE: arheozoologie, cultura Boian, Hârșova-tell, creșterea animalelor, vânătoarea, biometrie.

MOTS CLÉS: archéozoologie, culture Boian, Hârșova-tell, élevage, chasse, biométrie. 


\section{Introducere}

Tell-ul de la Hârșova (județul Constanța) este unul dintre siturile emblematice ale României (Fig. 1) dacă avem în vedere cercetările arheologice și studiile interdisciplinare efectuate aici de-a lungul timpului, mai ales după 1993. Tell-ul eneolitic este situat la baza versantului unei înălţimi stâncoase, pe malul drept al Dunării, în marginea de sud-est a oraşului Hârşova. Subliniem că este unul din cele mai mari tell-uri din Europa, depunerile arheologice având o grosime de circa $12 \mathrm{~m}$. Amplasat pe o stâncă de calcar ce se prelungeşte în Dunăre, tell-ul avea în vechime diametrele de aproximativ 200 x 150 m. Ulterior formării tell-ului, Dunărea şi-a mutat cursul către nord, erodând o mare parte din aşezare. Stratigrafia aşezării de la Hârşova-tell este complexă, vestigiile arheologice descoperite fiind atribuite culturilor Hamangia, Boian, Gumelniţa şi Cernavodă. Cercetările arheologice au fost întreprinse de către Doina Galbenu ${ }^{1}$ în anii 1961-1963, 1971, 1975, 1985, Dragomir-Nicolae Popovici şi Puiu Haşotti din 1985 până în 2000², iar între 2001-2017 colectivul științific a fost condus de Dragomir-Nicolae Popovici³. Din 1993 așezarea preistorică de la Hârșova-tell a beneficiat de colaborarea cu o echipă franceză condusă de Bernard Randoin şi Yannick Rialland (Ministerul Culturii din Franța). Această frumoasă și fructuoasă colaborare a permis implementarea unor diferite metode de cercetare arheologică pluridisciplinară care au făcut ca situl să devină un șantier școală pentru numeroase generații de studenți de la facultăţile de Istorie din Constanţa, Târgoviște și București, dar și de la facultatea de Biologie din București, mulți dintre ei făcând parte în prezent din colectivele arheologice de la diferite instituții din țară.

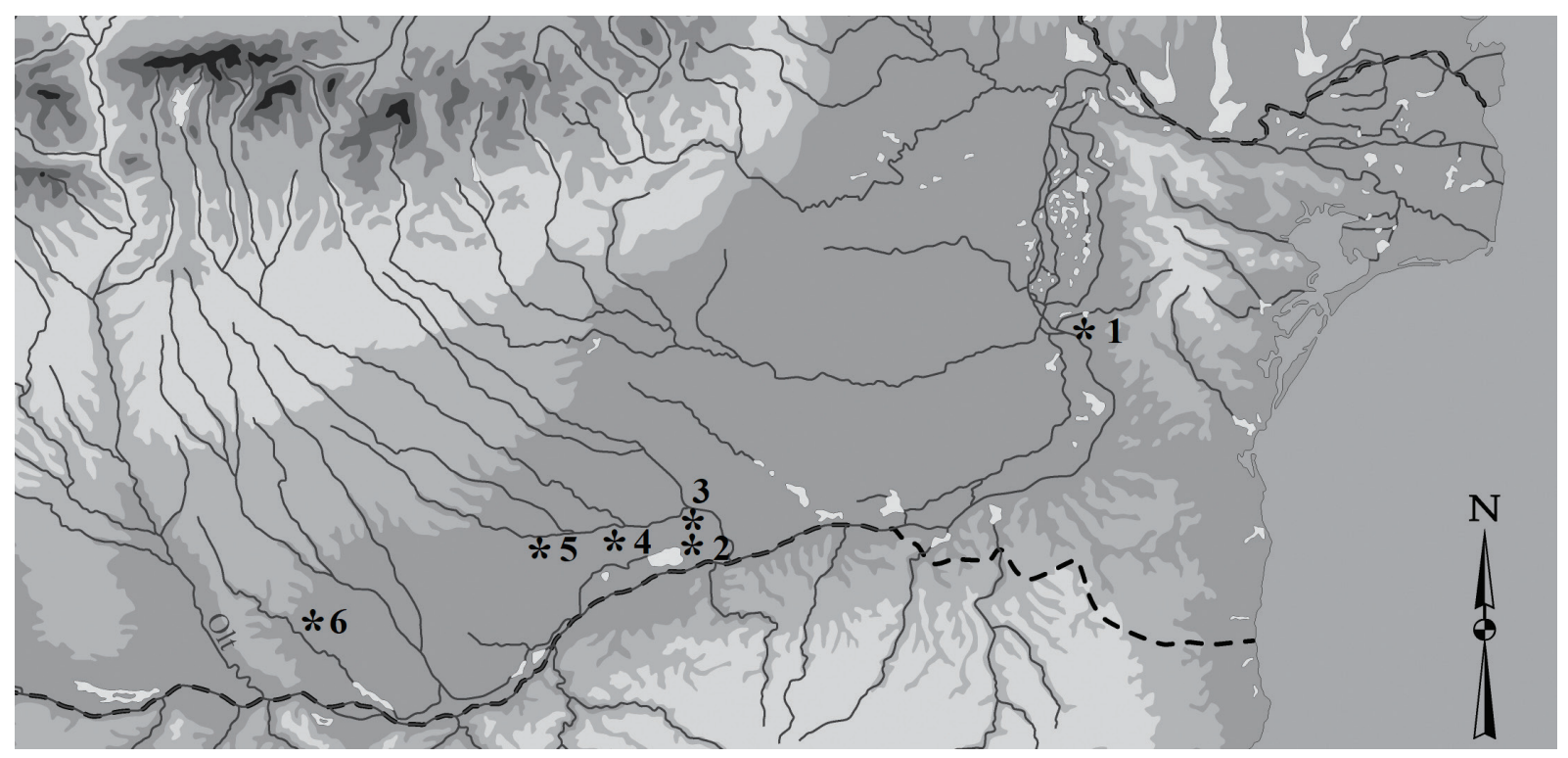

Figura 1. Poziția geografică a sitului de la Hârșova-tell (1) și a celorlalte așezări Boian Spanțov care prezintă studii de arheozoologie în sud-estul României (2 - Căscioarele; 3 - Radovanu; 4 - Tangâru; 5 - Izvoarele; 6 - Lăceni-Măgura).

Analize arheozoologice asupra faunei de la Hârşova-tell au fost realizate sistematic în timpul cercetărilor arheologice ${ }^{4}$, dar din păcate puține dintre acestea au fost publicate într-un context arheologic stratigrafic foarte precis, de cele mai multe ori acestea au prezentat datele într-un context mai mult cultural și general. Astfel nivelul Gumelnița A2 studiat în secțiunea B (SB) a beneficiat de cele mai multe analize acestea fiind atât clasice ${ }^{5}$, dar și superspecializate, cum ar fi studii de paleogenetică $\breve{6}^{6}$, izotopi ${ }^{7}$ sau morfometrie geometrică ${ }^{8}$. Informații asupra

1 Galbenu 1962; Galbenu 1966; Galbenu 1979.

2 Haşotti 1989; Haşotti 1997; Haşotti, Popovici 1992; Popovici, Haşotti 1992; Popovici et al. 1992; Popovici et al. 2000; Randoin, Popovici, Rialland 2000.

3 Vezi rapoartele de cercetare arheologică de la Hârșova tell publicate în Cronica Cercetărilor Arheologice din România din anii 1994-2007, 2010-2012, 2014, 2016 și 2017 (Cronica 1983-2017); Popovici, Randoin, Rialland 2001; Popovici et al. 2012; Popovici et al. 2014; Popovici et al. 2016.

4 Cronica 1983-2017.

5 Bălășescu, Moise, Radu 2005; Bălășescu, Radu, Moise 2005; Bălăşescu, Moise, Radu 2006; Bréhard, Bălășescu 2012; Bréhard et al. 2014; Desse-Berset, Radu 1996; Gál, Kessler 2002; Le Bailly et al. 2006; Moise 2000; Radu 2000; Radu 2011; Radu et al. 2016; Sárkány-Kiss, Boloș 1996.

6 Evin et al. 2015; Frantz et al. 2016; Frantz et al. 2019; Larson et al. 2007; Ollivier et al. 2013; Ollivier et al. 2016; Ollivier et al. 2018; Ottoni et al. 2017.

7 Balasse et al. 2016; Balasse et al. 2017a; Balasse et al. 2017b; Balasse et al. 2018.

8 Evin et al. 2015. 
faunei de mamifere din nivelul Boian Spanțov din secțiunea C (SC) au fost prezentate pentru prima dată într-un volum de sinteză ${ }^{9}$ asupra culturii Boian și Hamangia, de aici și necesitatea ca aceasta să fie prezentată mai pe larg.

Cercetările arheologice interdisciplinare efectuate în ultimii ani la baza tell-ului de la Hârşova în secțiunea C/proprietatea Potamianus (SC/pP) au permis desoperirea unor structuri de locuire şi a unor zone menajere care aparțin culturii Boian Spanțov și care au fost publicate sub forma a două rapoarte de săpătură extinse care privesc două

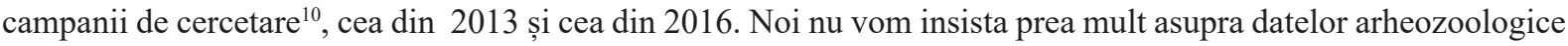
din $\mathrm{SC} / \mathrm{pP}^{11}$, acestea făcând obiectul unei viitoare publicații care va include mai multe campanii de cercetare și care vor privi numai nivelul Boian de la baza tell-ului, doar vom face câteva comparații punctuale în legătură cu evoluția paleoeconomiei animaliere ${ }^{12}$ din acest sit între nivelurile Boian Spanțov (secțiunile SC și SC/pP) și Gumelnița A2 (secțiunea B).

Din secţiunea C, de pe acest şantier arheologic, s-au recoltat în mod direct ("la ochi”) ca urmare a campaniilor de săpături din 1988 și 1989 (altimetric fiind între 7,20 - 8,60 m), diferite materiale paleofaunistice, în principal mamifere atribuite culturii Boian, faza Spanţov. La acest eşantion s-a mai adăugat un altul care provine dintr-o prelevare test dintr-o zonă menajeră din secţiunea C la care s-a aplicat sitarea sub jet de apă și care a fost studiat în 1994. Avantajele și dezavantajele sitării de sediment arheologic din diferite contexte au fost prezentate cu altă ocazie $^{13}$ şi de aceea nu vom insista asupra acestui subiect. În acest ultim eșantion s-au descoperit numeroase resturi de peşti ${ }^{14}$, dar şi alte resturi faunistice de la diferite clase de animale ${ }^{15}$.

O datare radiocarbon $\left({ }^{14} \mathrm{C}\right)$ a fost realizată în 2008 pentru acest nivel Boian Spanțov ${ }^{16}$ din SC pe un humerus distal de capră (Capra hircus) în laboratorul Belfast ${ }^{14} \mathrm{CHRONO}$ Centre din Irlanda de Nord (UBA-9631) grație proiectului internaţional Chronobos. Valoarea BP este de 5774+/-28, iar 2 sigma (95,4\%) este de 4702-4547 calBC. Aceasta este identică cu o altă datare obținută din locuința 109 descoperită în SC/pP în urma campaniei de cercetări arheologice din anul $2013^{17}$ fapt ce ar sugera contemporaneitatea dintre structurile arheologice studiate în SC cu cele din $\mathrm{SC} / \mathrm{pP}$.

Fauna din secțiunea C care provine din anii de săpături arheologice din 1988-1989 și 1994 a fost reunită și ea este destul de numeroasă, identificându-se circa 7649 resturi. Acestea aparţin unor diferite clase de animale: Bivalvia (scoici), Gastropoda (melci), Pisces (peşti), Reptile (broaşte ţestoase), Aves (păsări) și Mammalia (mamifere). Cele mai numeroase resturi aparţin peştilor 5095 (66,6\%), care sunt urmate ca pondere de către mamifere, cu 2284 (29,9\%) (Fig. 2).

\begin{tabular}{|l|c|c|}
\hline Clase de animale & NR & \% \\
\hline Bivalvia & 225 & 2,9 \\
\hline Gastropoda & 6 & 0,1 \\
\hline Pisces & 5095 & 66,6 \\
\hline Reptilia & 25 & 0,3 \\
\hline Aves & 14 & 0,2 \\
\hline Mammalia & 2284 & 29,9 \\
\hline Total resturi & $\mathbf{7 6 4 9}$ & $\mathbf{1 0 0 , 0}$ \\
\hline
\end{tabular}

Figura 2. Repartiția numerică şi procentuală a resturilor de faună descoperite în secțiunea C de la Hârșova-tell (Boian Spanțov).

Scopul acestei contribuții științifice este de a prezenta fauna de mamifere din secțiunea C, care nu a mai fost publicată niciodată în extenso, de aceea nu vom face și alte aprecieri asupra celorlalte clase de animale.

\footnotetext{
9 Bălășescu, Radu 2004.

${ }^{10}$ Popovici et al. 2014; Popovici et al. 2016.

${ }^{11}$ Popovici et al. 2014, 33-34; Popovici et al. 2014, 32-34.

${ }^{12}$ Vezi subcapitolul V.

${ }^{13}$ Popovici et al. 2002, 55-56.

${ }^{14}$ Desse-Berset, Radu 2006.

${ }^{15}$ Bălăşescu, Radu 2004.

16 Bréhard, Bălășescu 2012, 3169, tabel 1.

${ }^{17}$ Popovici et al. 2019.
} 


\section{Metodologie}

Determinările anatomice şi taxonomice au fost realizate cu ajutorul colecţiilor osteologice de referinţă ale Laboratorului de Arheozoologie din cadrul Centrului Naţional de Cercetări Pluridisciplinare „Alexandra Bolomey” din Muzeul Naţional de Istorie a României. De asemenea au fost consultate lucrările metodologice ale lui Barone ${ }^{18}$ şi Schmid ${ }^{19}$ pentru mamifere. Discriminarea dintre oaie şi capră a fost făcută pe baza scheletului post-cranian după criterile lui Boesneck şi colaboratori ${ }^{20}$ testate de Clutton-Brock şi colaboratori ${ }^{21}$ şi Prummel şi Frisch ${ }^{22}$; pentru resturile dentare, am utilizat lucrările lui Payne ${ }^{23}$, Helmer ${ }^{24}$ şi Halstead şi colaboratori ${ }^{25}$.

Vârstele de abataj (de sacrificare) au fost estimate după erupţiile dentare apelând la lucrarea lui Schmid ${ }^{26}$, iar pentru uzurile dentare am consultat lucrările lui Ducos ${ }^{27}$ şi Grant ${ }^{28}$ pentru bovine, Payne ${ }^{29}$ şi Helmer ${ }^{30}$ pentru ovicaprine şi Horard-Herbin $^{31}$ pentru suine. Corelarea datelor biologice cu cele zootehnice s-a realizat după Forest ${ }^{32}$.

Măsurătorile resturilor faunistice au fost realizate cu un şubler care prezintă o precizie instrumentală de 1/10 milimetri. Acestea au fost luate după recomandările lui von den $\operatorname{Driesch}^{33}$ (1976) şi ele se regăsesc în anexa cu date biometrice (Anexa 1). Cu toată imprecizia metodei de estimare a taliei (înălţimii la greabăn) datorată puternicelor allometrii în special la animalele domestice, aceasta a fost realizată utilizând coeficienţii reuniţi de către Udrescu și colaboratori ${ }^{34}$. Repartiția resturilor faunistice pe specii și elemente anatomice se regăsește în Anexa 2.

\section{Descrierea speciilor}

Din cele 2284 resturi de mamifere s-au determinat specific 1515 (66,3\%). În cadrul spectrului faunistic s-au descoperit atât specii de animale domestice: vita (Bos taurus), oaia (Ovis aries), capra (Capra hircus), porcul (Sus domesticus), câinele (Canis familiaris), cât şi sălbatice: calul (Equus ferus), bourul (Bos primigenius), cerbul (Cervus elaphus), căpriorul (Capreolus capreolus), mistrețul (Sus scrofa), vulpea (Vulpes vulpes), pisica (Felis silvestris), bursucul (Meles meles), vidra (Lutra lutra) și iepurele de câmp (Lepus europaeus) (Fig. 3).

Trebuie specificat că resturile de mamifere prezintă toate caracteristicile unor deşeuri menajere, pe suprafaţa lor identificându-se urme de descărnare (5\%), dezarticulare (7\%), ardere (2,7\%) şi dinţi (11\%). Materialul este destul de fragmentat, dar starea sa de conservare este totuşi destul de bună. Din cauza fragmentarităţii, dar şi a imposibilităţii de a determina cu precizie anumite resturi în cadrul statisticii apar şi alte rubricii, cum sunt: Bos taurus/Bos primigenius, Bos taurus/Cervus elaphus, Canis familiaris/Vulpes vulpes, Sus domesticus/Sus scrofa (Fig. 3).

Animalele domestice sunt preponderente, ele deţinând ca număr de resturi (NR) 82,9\%, iar ca număr minim de indivizi (NMI) 70,5\%, cele sălbatice prezintă 17,1\% ca NR şi 29,5\% ca NMI (Fig. 3).

\section{III.1 Animale domestice}

Bos taurus (vita domestică) prezintă cele mai numeroase resturi, $663(43,8 \%)$ care atestă prezenţa a 22 de indivizi prezumaţi $(23,2 \%)(\mathrm{Pl}$. I/1-2). Vârstele de sacrificare ale acestora sunt: un infans (4-6 luni), doi juvenili de 6-8 luni, doi juvenili de 12 luni, patru indivizi de 18 luni, doi de 2- $2^{1 / 2}$ ani, doi de $2^{1 / 2}-3$ ani, unul de 4 ani, 6 adulţi (între 4-8 ani), 2 adulţi bâtrâni (8-10 ani). Aceste vârste ne certifică faptul că animalele erau crescute pentru aportul lor în carne, dar şi pentru produsele lor secundare: lapte și produse lactate (vezi adulţii). Pe baza morfologiei a două procese cornulare s-au identificat două femele. Datele biometrice ne indică animale cu o robusteţe medie (Anexa

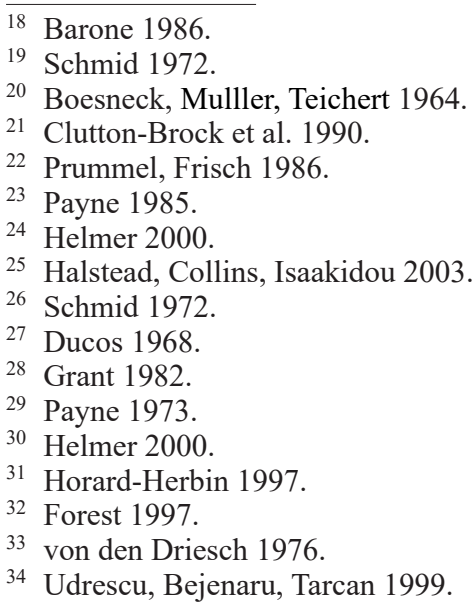


1). Din păcate nu s-a identificat nici un os întreg care să ne permită estimarea taliei şi din această cauză nu s-au putut face aprecieri asupra acesteia.

Separarea celor două specii de bovine (vită și bour) s-a realizat și pe baza datelor biometrice (Fig. $4^{35}$ și Anexa 1).

\begin{tabular}{|l|c|c|c|c|}
\hline Specia & NR & $\mathbf{\%}$ & NMI & $\mathbf{\%}$ \\
\hline Bos taurus & 663 & 43,8 & 22 & 23,2 \\
\hline Ovis aries & 69 & 4,6 & & \\
\hline Capra hircus & 30 & 2,0 & & \\
\hline Ovicaprine & 287 & 18,9 & 20 & 21,1 \\
\hline Sus domesticus & 130 & 8,6 & 12 & 12,6 \\
\hline Canis familiaris & 77 & 5,1 & 13 & 13,7 \\
\hline Total mamifere domestice & $\mathbf{1 2 5 6}$ & $\mathbf{8 2 , 9}$ & $\mathbf{6 7}$ & $\mathbf{7 0 , 5}$ \\
\hline Equus ferus & 1 & 0,1 & 1 & 1,1 \\
\hline Bos primigenius & 32 & 2,1 & 5 & 5,3 \\
\hline Cervus elaphus & 93 & 6,1 & 7 & 7,4 \\
\hline Capreolus capreolus & 3 & 0,2 & 2 & 2,1 \\
\hline Sus scrofa & 109 & 7,2 & 7 & 7,4 \\
\hline Vulpes vulpes & 4 & 0,3 & 1 & 1,1 \\
\hline Felis silvestris & 2 & 0,1 & 1 & 1,1 \\
\hline Meles meles & 2 & 0,1 & 1 & 1,1 \\
\hline Lutra lutra & 1 & 0,1 & 1 & 1,1 \\
\hline Lepus europaeus & 12 & 0,8 & 2 & 2,1 \\
\hline Total sălbatice & $\mathbf{2 5 9}$ & $\mathbf{1 7 , 1}$ & $\mathbf{2 8}$ & $\mathbf{2 9 , 5}$ \\
\hline Total determinate & $\mathbf{1 5 1 5}$ & $\mathbf{1 0 0}$ & $\mathbf{9 5}$ & $\mathbf{1 0 0}$ \\
\hline Bos taurus/Cervus elaphus & 10 & & & \\
\hline Bos taurus/Bos primigenius & 1 & & & \\
\hline Canis familiaris/Vulpes vulpes & 3 & & & \\
\hline Sus domesticus/Sus scrofa & 127 & & & \\
\hline Indeterminate & 616 & & & \\
\hline Total mamifere & $\mathbf{2 2 7 2}$ & & & \\
\hline Coarne de cerb & 12 & & & \\
\hline Total & $\mathbf{2 2 8 4}$ & & & \\
\hline
\end{tabular}

Figura 3. Repartiția numerică și procentuală a resturilor de mamifere descoperite în secțiunea C de la Hârșova-tell (Boian Spanțov).

Ovicaprinele (Ovis aries şi Capra hircus) sunt reprezentate de 386 resturi (25,5\%) care ne-au permis calcularea unui număr de 20 de indivizi (21,1\%). Din cele 386 de resturi de ovicaprine, doar 69 aparţin lui Ovis aries, iar 30 lui Capra hircus, restul nefiind determinate până la nivel de specie, datorită fragmentarităţii şi lipsei de criterii anatomice de diferenţiere. Vârstele de sacrificare ale cornutelor mici sunt: doi indivizi de 4 luni (humerus distal în curs de epifizare), doi de 9-12 luni, trei de 21-24 luni, doi de 2-3 ani, cinci de 4-6 ani, patru de 6-8 ani, doi de de 8-10 ani (toţi determinaţi pe baza dentiţiei). Studiul acestor vârste ne arată că aceste animale erau crescute mai mult pentru produsele lor secundare (lapte şi produse lactate) şi mai puţin pentru carne.

Resturile de oaie domestică (Ovis aries) identificate sunt mai numeroase decât cele de capră, raportul fiind de 2,3 la 1. Scheletul cefalic este slab reprezentat, doar două resturi, care nu ne permit să facem aprecierii asupra craniului acestei specii (Anexa 2). Descoperirea unui rest de astragal întreg ne-a permis estimarea taliei care are o valoare de 60,6 cm (indice Teichert). Valoarea taliei este cu puțin superioară valorii pentru cultura Boian $(58,2 \mathrm{~cm}, \mathrm{~N}=34$,

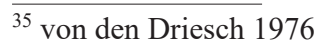


limite 52,1-69,5 cm) şi se încadrează în limitele întâlnite pentru acest animal în arealul acestei culturi. În general taliile calculate pe oasele tarsiene (calcaneu și astragal) dau valori mai mari decât cele estimate pe oasele lungi de aceea acestea trebuie luate în considerare cu multă prudență ele fiind după părerea noastră supraevaluate ${ }^{36}$.
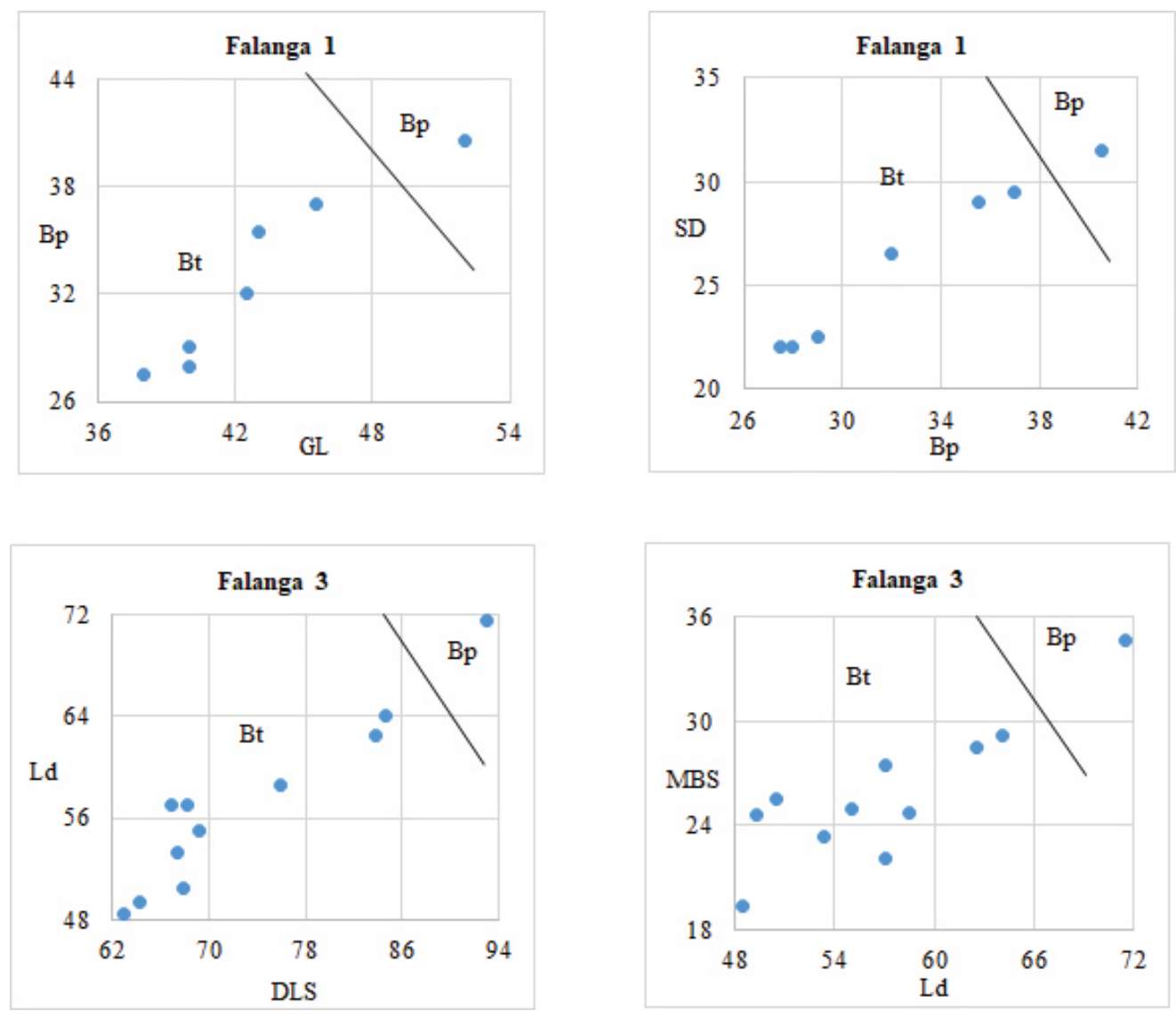

Figura 4. Separarea biometrică a celor două specii de bovine (Bos taurus - Bt și Bos primgenius - Bp) pe diferite elemente anatomice. Măsurătorile sunt în milimetri și codurile acestora sunt după von den Driesch .

În ceea ce priveşte capra domestică (Capra hircus) putem spune că aceasta prezenta coarne de tip săbiat. Două dintre piese care aparţin unor femele au putut fi şi dimensionate (Pl. I/3-4). Pe baza unui metacarp întreg s-a putut calcula talia (Anexa 1), care are o valoare de $61,8 \mathrm{~cm}$ (indice $S c h r a m m$ ), cu puțin superioară ovinelor. Această valoare este superioară celei întâlnite pentru cultura Boian $(57,5 \mathrm{~cm}, \mathrm{~N}=12$, limite $50,5-62,6 \mathrm{~cm})$.

Porcul (Sus domesticus) este prezent cu 130 de resturi $(8,6 \%)$ care aparţin unui număr de 12 indivizi prezumaţi $(12,6 \%)$. Vârstele lor de sacrificare determinate exclusiv pe baza dentiţiei (Pl. I/5-6) sunt: doi indivizi de 6-8 luni, doi de 8-10 luni (dintre care unul este femelă), trei de 10-12 luni (o femelă), trei de 16-18 luni (o femelă şi un mascul), o femelă de 24 luni şi unul de 30-36 luni. Raportul dintre imaturi şi maturi sexuali este de 1,4:1 (7:5) în condiţiile în care noi considerăm această maturitate ca fiind la 12 luni ${ }^{37}$. Existenţa unui metacarp IV întreg ne-a permis obţinerea unei talii de $71,8 \mathrm{~cm}$ (indice Teichert) care este mai mică decât cea întâlnită în aşezarea de la Isaccea $\operatorname{Suhat}^{38}(81,4 \mathrm{~cm})$.

Separarea celor două specii de suine (porc și mistreț) s-a putut realiza și pe baza datelor biometrice (Fig. 5 și anexa 1). Din păcate faptul că multe animale sunt de vârstă tânără (sub 12 luni), înainte de a se epifiza majoritatea oaselor a permis mai mult evidențierea speciei sălbatice. Biometria a facilitat într-un singur caz (tibie distală epifizată) și observarea existenței metișilor, rezultat al încrucişării dintre porc și mistreț. Din păcate nu putem afirma dacă acest metis se regăsea în cadrul populației domestice sau sălbatice.

Câinele (Canis familiaris) este bine reprezentat ca număr de resturi, 77 (5,1 \%) care au permis identificarea unui număr de 13 indivizi (13,7 \%). Vârstele acestor animale sunt: un nou născut/infans, un juvenil (ambii determinaţi pe baza a două radiusuri), 10 adulţi şi un adult bătrân (toţi determinaţi pe baza dentiţiei). Pe trei dintre oase

\footnotetext{
36 Bălășescu, Radu 2004, 137.

37 Forest 1997, fig. 3.

38 Bălășescu, Radu 2004, 126.
} 
s-au pus în evidenţă urme care atestă consumul acestui mamifer în scopuri alimentare. Astfel pe un fragment de neurocraniu, la nivelul condilului occipital stânga se observă trei urme grosiere de silex (dezarticulare) datorate desprinderii craniului de coloana vertebrală precum și urme discrete de ardere (Pl. I/7-8); pe un fragment diafizar de ulnă se observă urme fine de descărnare, iar pe un fragment proximal de femur, la nivelul capului şi colului femural se observă urme grosiere şi fine ale unor unelte de tăiat (probabil silex) care atestă dezarticularea femurului de coxal şi descărnarea. Datele biometrice se încadrează în valorile cunoscute pentru câinele din cultura Boian ${ }^{39}$.
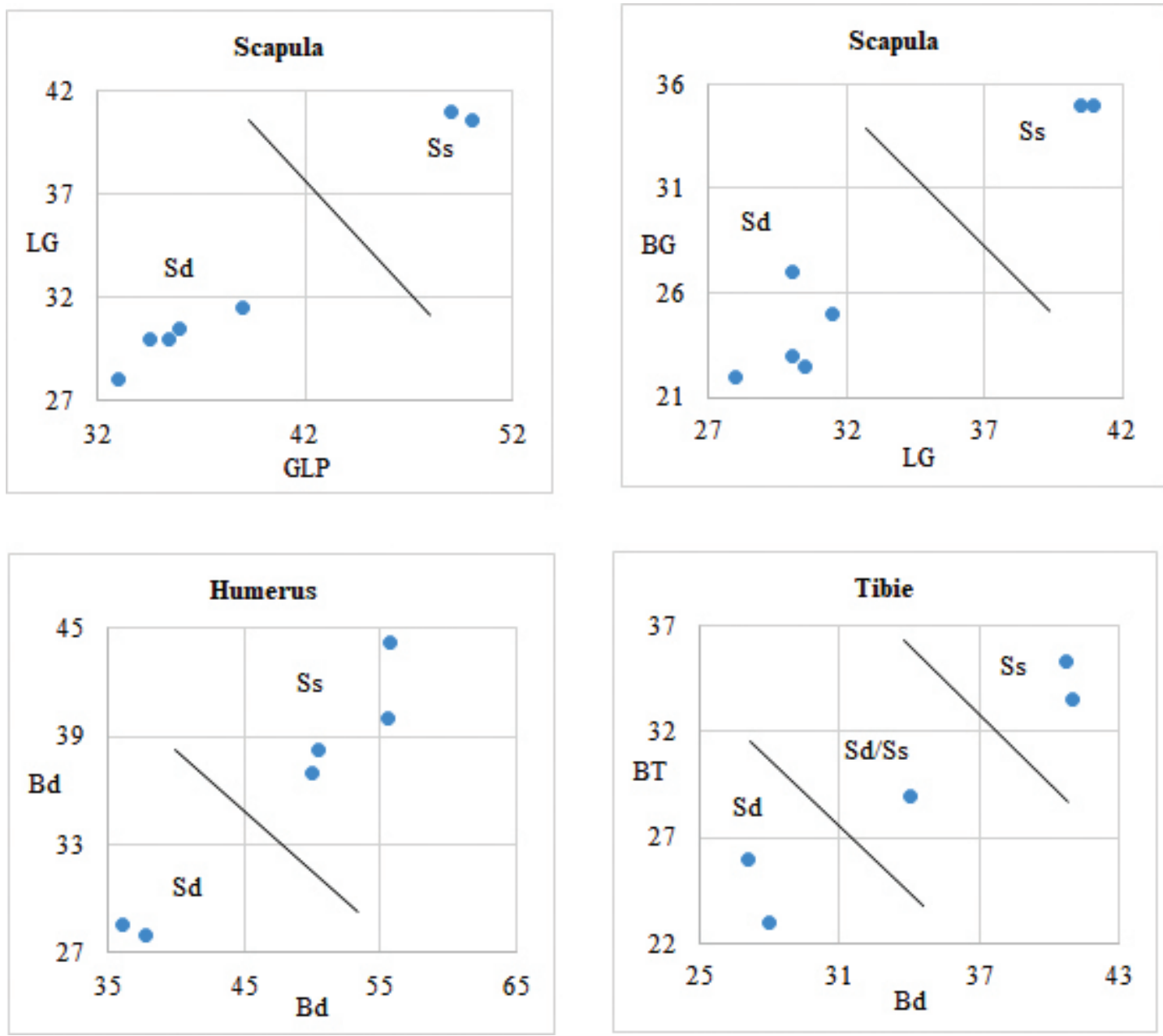

Figura 5. Separarea biometrică a celor două specii de suine (Sus domesticus - Sd; Sus scrofa - Ss; Sus domesticus/Sus scrofa - Sd/

Ss) pe diferite elemente anatomice. Măsurătorile sunt în milimetri și codurile acestora sunt după von den Driesch (1976).

\section{III.2. Animale sălbatice}

Calul sălbatic (Equus ferus) este reprezentat de un fragment de tibie distal epifizată care a aparţinut unui individ mai mare de 2 ani.

Bourul (Bos primigenius) este prezent prin 5 indivizi (5,3\%) care au fost determinaţi pe baza a 32 de resturi $(2,1 \%)$. Vârstele de sacrificare ale acestora sunt: unul sub 3 ani (calcaneu neepifizat, dar de dimensiuni foarte mari, cu o lungime maximă de $153 \mathrm{~mm}$ ), 4 adulţi determinaţi pe baza dentiţiei. Cu toate că puţine dintre piese au putut fi din păcate dimensionate (Fig. 4 și Anexa 1), datele biometrice se înscriu în valorile deja cunoscute pentru cultura Boian $^{40}$.

Cerbul (Cervus elaphus) cu cele 105 resturi determinate $(6,1 \%$ ) care au aparţinut unui număr de 7 indivizi prezumaţi (7,4\%) este una dintre speciile cele mai vânate la Hârșova-tell în nivelul Boian-Spanţov (Pl. II/1-3). În material s-au identificat și 12 resturi de fragmente de coarne. Din păcate este dificil de afirmat dacă provin de la animale vânate sau dacă acestea au fost culese din zonele împădurite din preajma sitului în sezonul cald când aceste ele-

39 Bălăşescu, Radu 2004, 123-124.

40 Bălășescu, Radu 2004, 177-181. 
mente anatomice cădeau de pe craniul masculilor și de aceea au fost cuantificate separat (Fig. 3 și Anexa 2). Unul dintre indivizii vânaţi avea o vârstă de 2,5 ani (radius distal în curs de epifizare), restul fiind adulţi (peste 3,5 ani). Cel puțin doi dintre aceștia sunt de sex mascul, fiind vânaţi în perioada septembrie-martie (toamnă-iarnă), dovadă fiind fragmentele de neurocraniu ce prezintă cornul pe peduncul ${ }^{41}$.

Căpriorul (Capreolus capreolus) este certificat doar prin trei resturi care aparţin la doi indivizi: unul sub 18 luni (falangă 1 neepifizată proximal) şi un altul de peste 18 luni (tibie epifizată distal şi phalangă 1 epifizată proximal).

Mistreţul (Sus scrofa) prezintă numărul cel mai mare de resturi identificate dintre speciile sălbatice, 109 (7,2\% - Pl. II/4-6; Fig. 5), care aparţin unui număr de şapte indivizi (7,4\%). Aceștia sunt toți adulţi, dintre care doar unuia putem să-i atribuim o vârstă mai precisă pe baza dentiţiei, de 30-36 luni. De asemenea prin intermediul dentiţiei s-au mai identificat un mascul şi două femele. Descoperirea unor oase întregi (patru calcanee şi un astragal) a permis evaluarea taliei la greabăn (indice Teichert) care are o valoare de 101,6 cm $(\mathrm{n}=5$; limite 95,4-105,3 cm). Aceasta este superioară valorii descoperite pentru cultura Boian ${ }^{42}$ care este de 99,4 cm (N=14, limite 91,3-105,3 cm).

Carnivorele sunt slab reprezentate ca număr de resturi $(9-0,6 \%)$ şi ca număr minim de indivizi $(4-4,4 \%)$. Speciile identificate sunt: Vulpes vulpes (4 resturi - Pl. II/7), Felis silvestris ( 2 - Pl. II/8), Meles meles $(2-\mathrm{Pl}$. III/1), Lutra lutra (1 - Pl. III/2), fiecărui taxon aparţinându-i câte un singur individ adult.

Iepurele de câmp (Lepus europaeus) a fost identificat prin 12 resturi (0,8\% - Pl. III/3-4) care aparţin la doi indivizi adulţi (coxale).

\section{Exploatarea mamiferelor la Hârșova-tell (nivelul Boian Spanțov - secțiunea C)}

Studiul arheozoologic ne arată că populația Boian Spanţov se ocupa în principal cu activitatea de creștere a animalelor, lucru dovedit de procentajul relativ ridicat al speciilor domestice $(82,9 \%$ ca NR și $70,5 \%$ ca NMI Fig. 3 și 6). Dintre animalele domestice ponderea cea mai mare o au bovinele, care sunt urmate de către ovicaprine și porcine. Studiul vârstelor de sacrificare ale cornutelor mari și mici ne arată că la bovine se observă o exploatare mixtă, atât pentru carne cât şi pentru diferite produse secundare, în timp ce la ovicaprine se remarcă o exploatare mai mult pentru produsele secundare (lapte) și în subsidiar pentru producția de carne. Porcul este exploatat prin excelență pentru carne și grăsime, iar studiul vârstelor de abataj ne arată consumul unei cărni de foarte bună calitate, dat fiind faptul că cele mai multe animale sacrificate au sub 12 luni, ele neatingând încă maximul ponderal.

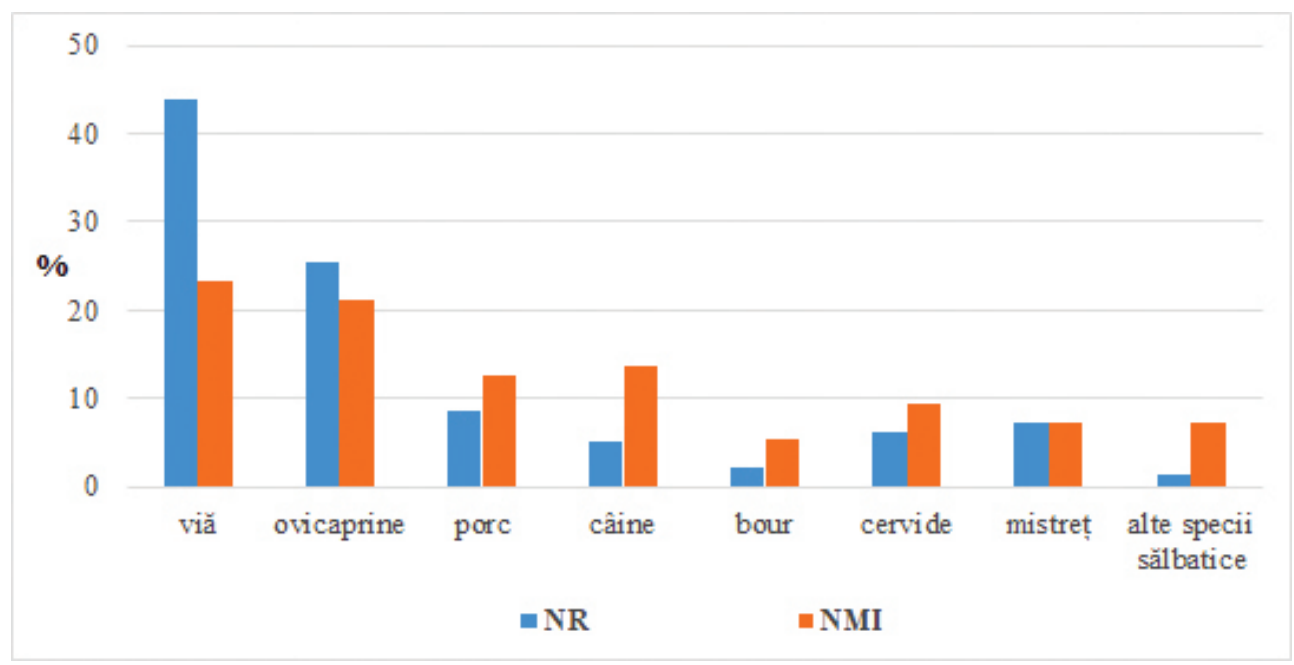

Figura 6. Repartiția procentuală a numărului de resturi (NR) și a numărului minim de indivizi (NMI) ale mamiferelor descoperite în secțiunea C de la Hârșova-tell (Boian Spanțov). Legendă: cervide - cerb și căprior; alte specii sălbatice cal, vulpe, bursuc, pisică, vidră, iepure de câmp.

Câinele are și o funcție alimentară, pe lângă cea de paznic al turmelor, locuințelor și companion al omului, dar importanța sa în cadrul paleoeconomiei animaliere nu este atât de mare, având în vedere talia sa modestă.

\footnotetext{
${ }_{41}$ Schmid 1977, 90, figura 26.

${ }^{42}$ Bălășescu, Radu 2004, 171.
} 
Vânatul este relativ bine reprezentat ca număr de specii (10), dar frecvența sa este redusă (17,1\% NR şi 29,5\% NMI - Fig. 6) în comparație cu cea a animalelor domestice. Primul loc este disputat de către mistreț (7,2\% NR şi 7,4\% NMI) și cerb (6,1 NR și 7,4\% NMI), secondate la mare distanță de către bour (2,1\% NR și 5,3\% NMIFig. 6). Ceilalți taxoni sălbatici au o importanță redusă, dar prezența lor chiar și în aceste condiții demonstrează interesul acestei comunități pentru această resursă de hrană care probabil se găsea într-o pondere relativ mare în mediul înconjurător al sitului situat pe malul Dunării. Vânătoarea se desfăşura cu succes atât în sezonul cald, cât și în cel rece, dacă avem în vedere cei doi masculi de cerb vânați în perioada septembrie-martie când aceste animale prezintă coarnele pe craniu.

\section{Evoluția paleoeconomiei animaliere la Hârșova-tell între nivelurile Boian Spanțov (SC/pP și SC) și Gumelnița A2 (SB).}

Cercetările de la Hârșova-tell realizate în ultimii 27 de ani au vizat cel mai mult studiul nivelului Gumelnița A2 din secțiunea $\mathrm{B}^{43}$ ceea ce ne-a permis să facem o comparație între cele două niveluri. În demersul nostru știinţific am avut în vedere și datele faunistice preliminare publicate din nivelul Boian Spanțov din SC/pP $\mathrm{P}^{44}$ pe care le-am însumat pentru a avea o ideea mai clară asupra faunei de la baza tell-ului. Specificăm că materialele faunistice din SB și SC/pP provin dintr-o serie de structuri arheologice care au fost sistematic date la sită prin jet de apă, ceea ce a permis de cele mai multe ori recoltarea întregului spectru faunistic, în comparație cu SC unde numai o zonă menajeră a fost studiată și sistematic sitată.

Chiar și în aceste condiții eșantioanele pentru cele trei secțiuni sunt reprezentative, ele depăşind peste 1500 de resturi de mamifere determinate, SC cu 1515 (SC - BS), SC/pP cu 1586 (SC/pP - BS), ambele fiind datate Boian Spanțov, în timp ce în SB care este încadrată în Gumelnița A2 (SB - GA2) s-au identificat 5310 fragmente de mamifere încadrate taxonomic. Raportul dintre mamiferele domestice și sălbatice este net în favoarea celor domestice în toate secțiunile, dar se observă că ponderea acestora și deci implicit a importanței activităţii de creștere a animalelor scade între baza tell-ului (90,9\% în SC/pP și 82,9\% în SC) spre partea superioară (76\% în SB) ceea ce ar sugera că ponderea vânătorii crește între Boian Spanțov (9,1\% în SC/pP și 17,1\% în SC) și Gumelniţa A2 (24\% în SB) (Fig. 7).

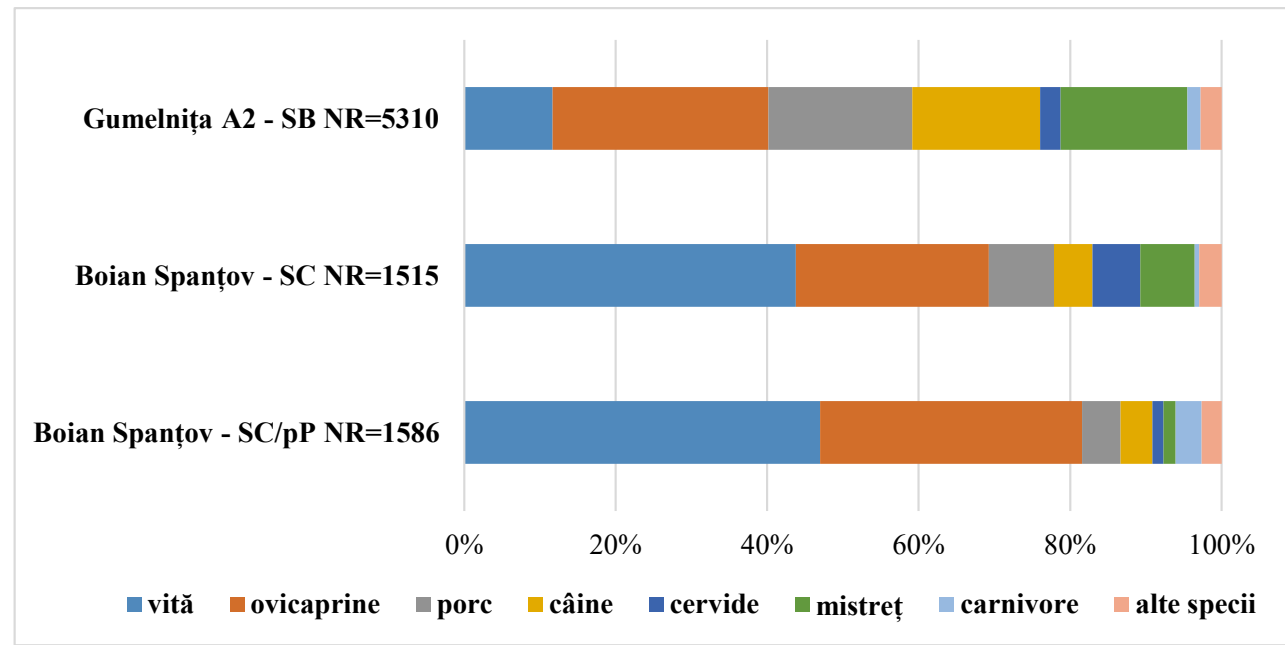

Figura 7. Comparații ale ponderii procentuale ale numărului de resturi ale speciilor de mamifere descoperite în diferite contexte culturale și secțiuni arheologice de la Hârșova tell. Legendă: cervide - cerb și căprior; carnivore lup, vulpe, pisică, bursuc, jder, vidră, bursuc; alte specii - bour, cal, castor și iepure de câmp.

În ceea ce privește activitatea de creștere a animalelor observăm că în nivelurile Spanțov, bovinele sunt cele mai reprezentative cu procentaje care depășesc peste 40\% (47\% în SC/pP - BS și 43,8\% în SC - BS), pentru ca în Gumelnița A2 acestea să scadă foarte mult până la 11,6\% (SB - GA2). Locul secund este ocupat de către ovicaprine care au pondere importantă la baza tell-ului de 34,6\% în SC/pP - BS, care scade spre 25,5\% în SC - BS, pentru ca apoi să ajungă la 28,5\% în SB - GA2 (Fig. 7). Câinele care este utilizat și în alimentaţie în toate nivelurile prezintă o creștere impresionată de la 4,2\% în SC/pP - BS, la 5,1\% în SC - BS ca să atingă 16,9\% în SB - GA2

\footnotetext{
43 Bălășescu, Radu, Moise 2005; Brehard, Bălășescu 2012.

44 Popovici et al. 2014, 33-34; Popovici et al. 2014, 32-34.
} 
(Fig. 7). Cea mai spectaculoasă evoluție ca pondere o are porcul care crește de la 5\% în SC/pP - BS la 8,6\% în SC - BS şi ajunge la 19\% în SB - GA2.

Acest fenomen de creștere a ponderii porcului a fost observat și în alte tell-uri din sud-estul României ${ }^{45}$ care prezintă mai multe niveluri culturale (diferite faze ale culturii Boian şi Gumelniţa). Acest lucru a fost pus în evidenţă în aşezările de la Vlădiceasca (niveluri culturale Boian-Vidra, Gumelniţa A1, A2 şi B1) şi Drăgăneşti-Olt, Gumelniţa şi Vităneşti (niveluri Gumelniţa A2 şi B1). Ponderea crescută a porcinelor sugerează în perioada eneoliticului dezvoltat existenţa unor comunităţi sedentare, stabile, care exploatează din punct de vedere paleoeconomic un anumit teritoriu, dar care totuşi prezintă strategii diverse ce diferă de la o zonă la alta.

Vânatul este bine reprezentat ca număr de taxoni, peste 10 în nivelurile Spanțov (SC/pP și SC) și atinge 15 specii în SB - GA2, ponderea sa crescând între Boian Spanțov (9,1\%) și Gumelnița A2 (24\%). Speciile cele mai interesante din punct de vedere cinegetic sunt mistrețul și cervidele - cerbul și căpriorul, dar mai ales cerbul. Astfel mistrețul crește de la 1,6\% în SC/pP - BS, la 7,2\% în SC - BS și ajunge la 16,8\% în SB - GA2, în timp ce cervidele cresc de la $1,5 \%$ în SC/pP la 6,3\% în SC - BS ca apoi frecvența lor să scadă la 2,7\% în SB - BS (Fig. 7). Ponderea carnivorelor sălbatice scade de la 3,4\% în SC/pP - BS la 1,7\% în SB - GA2 (Fig. 7). Bourul are o poziție interesantă, acesta nefiind identificat până în acest moment în SC/pP - BS, dar a fost descoperit în SC - BS $(2,1 \%)$ şi în SB - GA2 (1\%). Ceilalți taxoni sălbatici au o importanță extrem de redusă în SC/pP - BS și SB - GA2 (Fig. 7).

Aparent primele comunități Boian care au început să formeze și să locuiască pe tell nu erau foarte mult interesate de vânat. În evoluția tell-ului se observă cum ponderea mai ales a porcului, câinelui și a mistrețului crește în detrimentul bovinelor domestice (Fig. 7).

În cadrul evoluției paleoeconomiei animaliere a tell-ului de la Hârșova se constată că primele comunităţi Boian Spanțov practicau în special creșterea bovinelor și a ovicaprinelor, iar vânatul avea o pondere relativ redusă, pentru ca în Gumelnița A2 să observăm că aceste populații exploatau ovicaprinele și porcinele, iar vânatul crește ca importanță (Fig. 7), existând un interes mult mai mare pentru acesta în condițiile unei sedentarizări accentuate a acestor populații.

$\mathrm{Cu}$ siguranță sedentarizarea de-a lungul mai multor generații ale comunităţilor Boian și apoi a celor Gumelnița la Hârşova-tell determină o schimbare în paleoeconomia animalieră a acestora care trec de la o exploatare a bovinelor la cea a porcinelor, în timp ce ponderea ovicaprinelor rămâne relativ constantă în condițiile în care o populație mult mai stabilă și mai sedentară devine mult mai interesată şi de exploatarea mediului înconjurător dacă avem în vedere creșterea frecvenței vânatului în Gumelnița A2.

Posibil că reducerea importanței bovinelor de-a lungul acestei evoluții crono-culturale să fie legată și de o serie de modificări alte mediului (poate și climatice) din preajma sitului, care probabil, în condițiile unei supraexploatării prin păşunat în perioada Boian Spanțov să nu mai fie atât de propice exploatării bovinelor, acest lucru având loc și în condițiile în care importanța porcinelor crește de o manieră foarte importantă, acestea hrănindu-se mai ales cu resturile menajere ale comunității gumelnițene ${ }^{46}$.

\section{Comparații arheozoologice cu alte situri Boian faza Spanțov}

În cadrul acestui subcapitol am luat în considerare numai datele care provin din SC care fac obiectul acestui articol. Nu am considerat necesar să facem apel și la datele din SC/pP având în vedere că acestea urmează să fie publicate complet în viitorul apropiat.

De-a lungul timpului s-au realizat extrem de puține studii arheozoologice în alte situri Boian, faza Spanțov. Astfel noi am putea recenza așezările de la Căscioarele ${ }^{47}$ și Radovanu ${ }^{48}$ din județul Călărași, Izvoarele ${ }^{49}$ și Tangâru ${ }^{50}$ din județul Giurgiu și Lăceni-Măgura ${ }^{51}$ din județul Teleorman. Eșantioanele faunistice sunt extrem de variate ca număr de resturi, astfel la Lăceni-Măgura avem cel mai mic eșantion faunistic cu 231 resturi de mamifere determinate, la Căscioarele 339, la Tangăru 421, în timp ce la polul opus se găsesc așezările de la Izvoarele cu 1136, Hârșova

\footnotetext{
45 Bălășescu, Radu, Moise 2005, 223-224.

${ }^{46}$ Balasse et al. 2016.

47 Bolomey 1981.

48 Necrasov 1973; Știrbu 1980.

49 Necrasov, Ghiorghiu 1970.

50 Necrasov 1959.

${ }^{51}$ Bălășescu 2014.
} 
tell - secțiunea C cu 1515 și cea de la la Radovanu care a beneficiat de două studii - $464^{52}$ şi $4239^{53}$, deci cu un total de 4703 resturi de mamifere identificate.

Din păcate studiul de la Căscioarele al nivelului Boian Spanţov ${ }^{54}$ prezintă resturile de bovine şi suine însumate ceea ce face destul de dificilă luarea în considerare a acestui eșantion. Totuși parcurgerea cu atenție a articolului, și mai ales analiza fină a datelor biometrice, ne permite să separăm fragmentele respective pe specii domestice (vită și porc) și sălbatice (bour și mistreț) cu unele rezerve mai ales în cazul suinelor.

În toate așezările Boian Spanțov se observă că mamiferele domestice sunt predominante cu procentaje care depășesc 82\% la Hârșova tell (SC) și care ajung în majoritatea siturilor la peste $90 \%$, ceea ce sugerează importanţa activității de creștere a animalelor în cadrul acestor comunităti preistorice (Fig. 8).

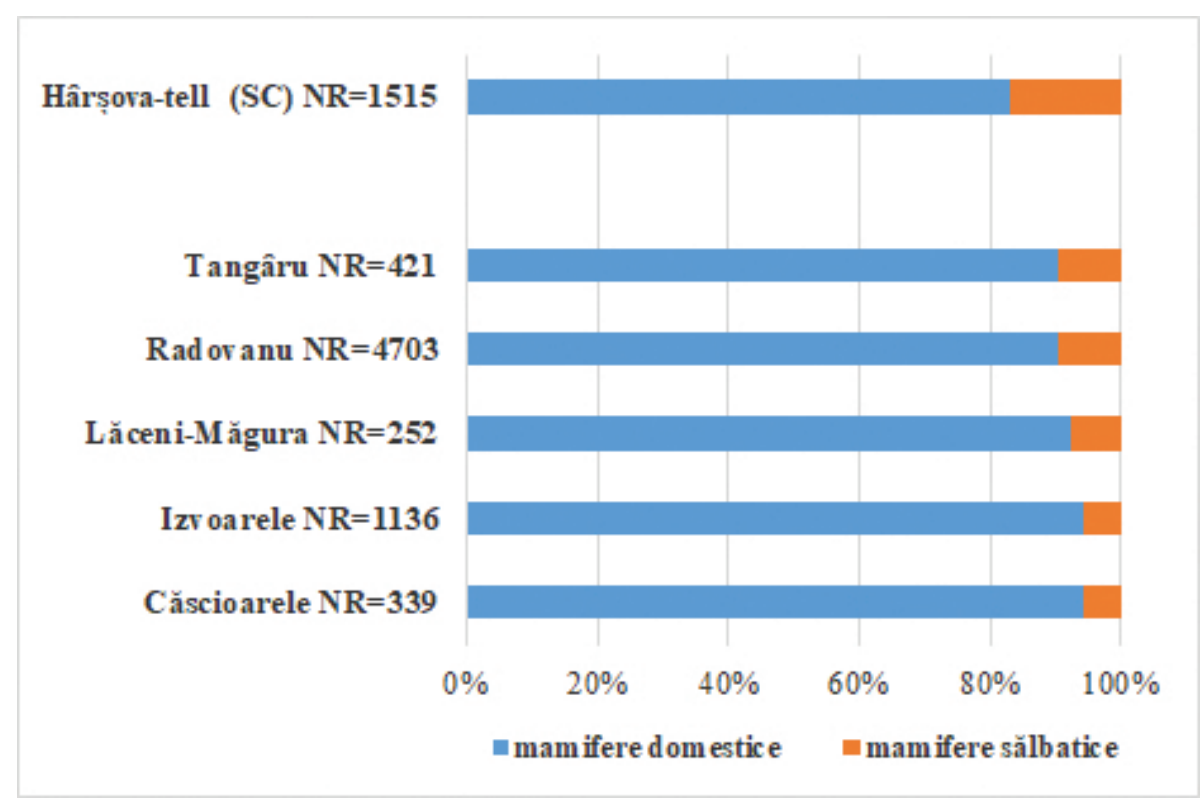

Figura 8. Comparații ale ponderii mamiferelor domestice și sălbatice descoperite în diferite situri Boian, faza Spanțov.

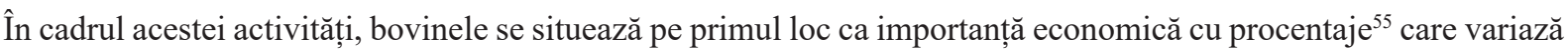
între 52,8\% la Hârșova-tell și 75,1 \% la Lăceni Măgura, acestea fiind urmate la mare distanță de către ovicaprine sau porcine care își dispută locul doi (Fig. 9). Astfel la Izvoarele, Lăceni-Măgura și Hârşova-tell cornutele mici se situează pe locul secund, în timp ce la Căscioarele, Radovanu și Tangâru porcinele le depășesc ca frecvență pe ovicaprine. În toate siturile ovinele sunt mai numeroase decât caprinele. În general procentajele atinse de către ovicaprine se situează între 9,7\% la Căscioarele și 30,7\% la Hârşova tell, iar cele ale porcinelor sunt între 4,7\% la Lăceni-Măgura și 25,8\% la Radovanu (Fig. 9). Câinele are o pondere care variază între 2,2\% la Căscioarele şi 6,1\% la Hârșova-tell și Tangâru. Menționăm că specia era utilizată în alimentație și la Izvoarele (4,7\%), dar fenomenul era întâlnit și în alte situri ale culturii Boian (Isaccea Suhat și Siliștea Conac), dar în faza Giulești ${ }^{56}$. De asemenea, în mai multe așezări Gumelnița, cum ar fi Borduşani-Popină, Hârșova-tell, Măriuţa, Sultana Malu Roșu, Vităneşti, Taraschina s-a observat că specia Canis familiaris este folosită şi în alimentaţie, dacă avem în vedere urmele de tăiere (dezarticulare şi descărnare) și de ardere, dar și că blana era utilizată ${ }^{57}$.

Vânatul reprezintă o ocupație secundară de suplimentare a rezervelor de carne, care permite și aprovizionarea cu alte produse cum ar fi pieile, blănurile, oasele, coarnele, etc. Numărul de taxoni sălbatici identificați este extrem de variabil între 6 la Căscioarele și 10-12 la Hârșova-tell (SC) și respectiv Radovanu. Numărul de taxoni este în strânsă legătură și cu mărimea eșantioanelor, care în cazul ultimelor două situri sunt și cele mai bogate în număr de resturi. În cadrul figurii 10 nu am reprezentat siturile de la Căscioarele și Lăceni-Măgura, deoarece ponderea mamiferelor sălbatice este extrem de redusă, de sub 30 de resturi, iar aşezarea de la Tangăru, cu 40 de resturi, nu prezintă o

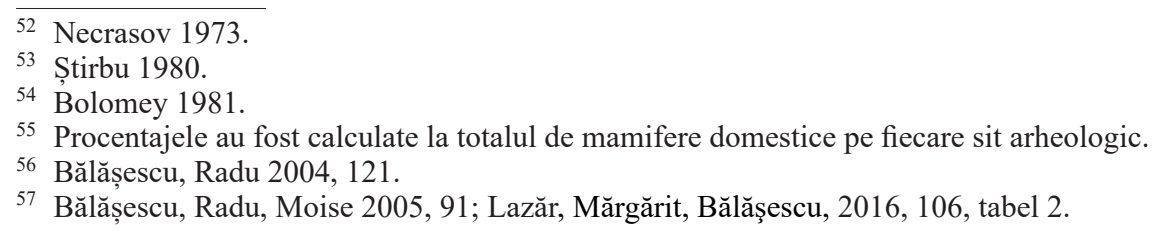


repartiție numerică a acestora pe specii. O constantă a tuturor siturilor Boian Spanțov este faptul că cervidele care reunesc cerbul și căpriorul sunt animalele cele mai vânate ${ }^{58}$ (și în special cerbul) cu procente între $37 \%$ și $58 \%$, cu excepția așezării de la Hârșova-tell unde acestea sunt depășite de către mistreț (42,1\% versus 37,1\%). Locul doi este disputat de mai mulți taxoni, astfel la Izvoarele avem mistrețul, la Radovanu se observă iepurele de câmp (Fig. 10), în timp ce la Căscioarele și Lăceni-Măgura se impune bourul. Situațiile sunt extrem de variate și ne arată adaptări și exploatări ale animalelor în diferite medii extrem de diverse de către aceste comunități.

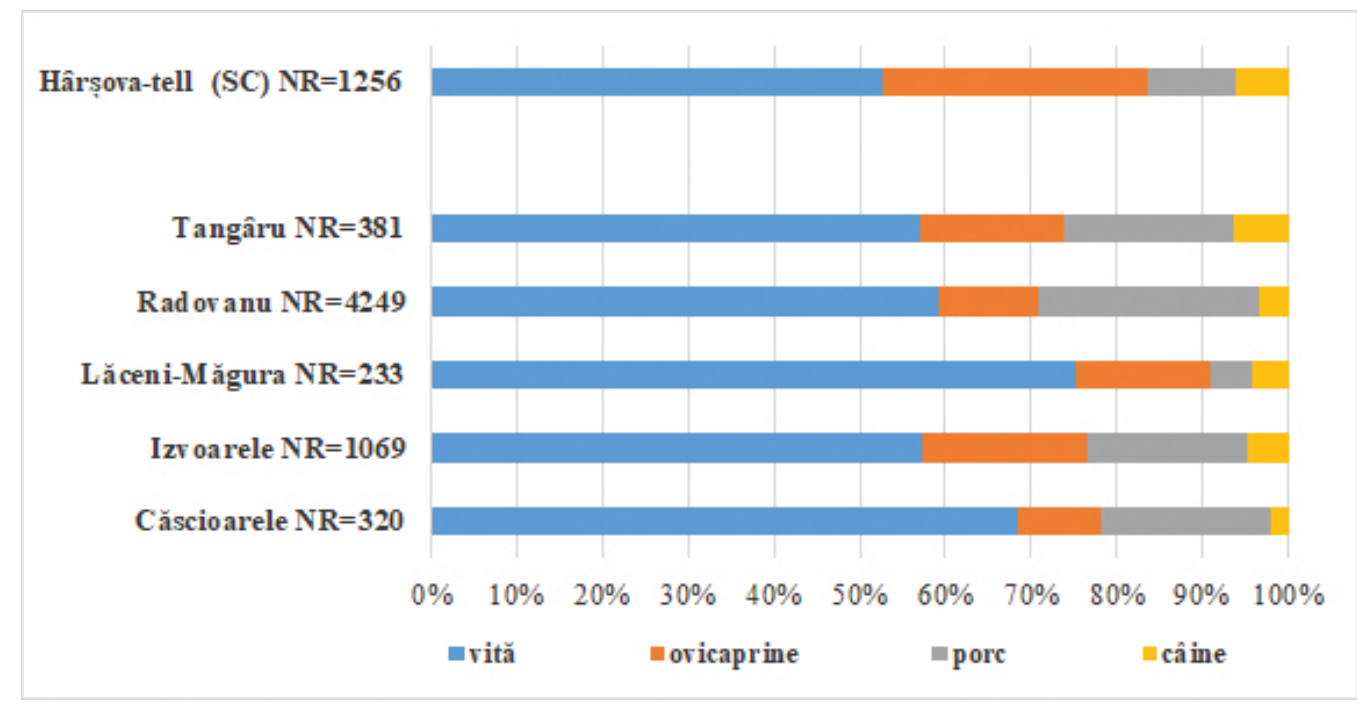

Figura 9. Comparații ale ponderii procentuale ale numărului de resturi ale speciilor de mamifere domestice descoperite în diferite situri Boian, faza Spanțov.

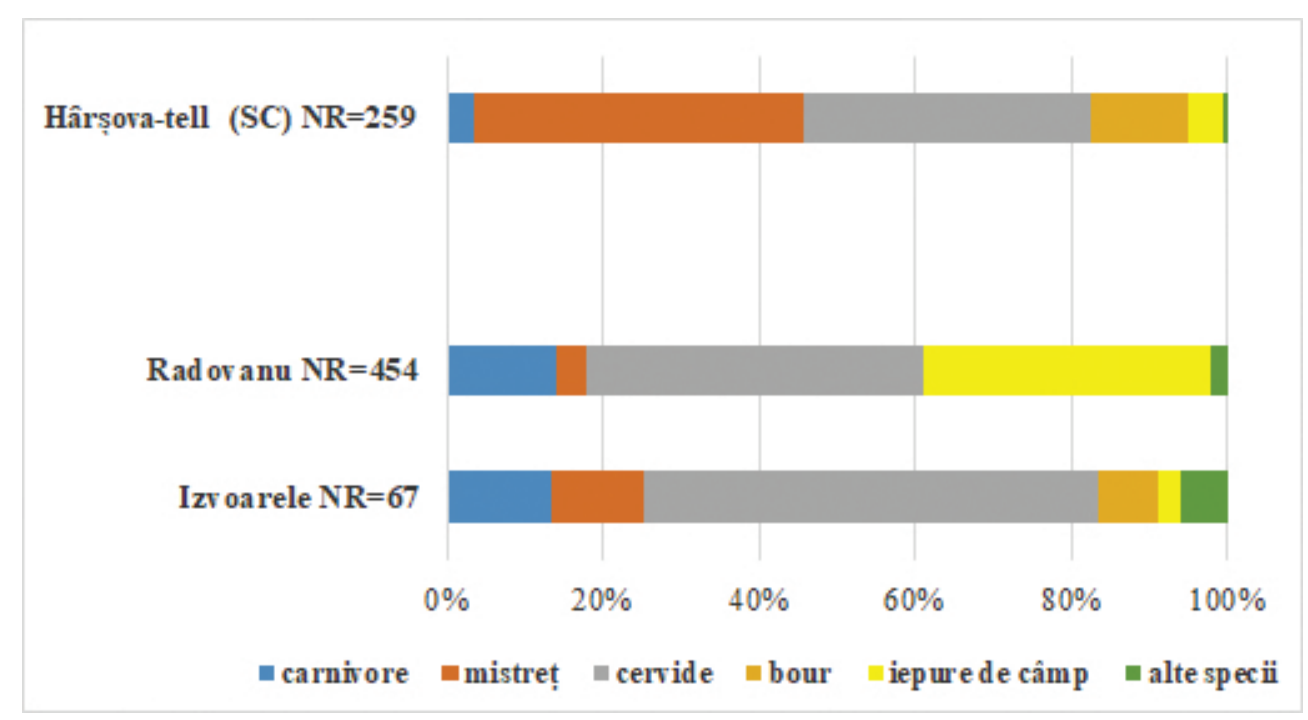

Figura 10. Comparații ale ponderii procentuale ale numărului de resturi ale speciilor de mamifere sălbatice descoperite în diferite situri Boian, faza Spanțov. Legendă: carnivore - lup, vulpe, bursuc, vidră, dihor, pisică, urs; cervide - cerb și căprior; alte specii - castor și cal.

\section{Concluzii}

Studiul arheozoologic al faunei de mamifere din nivelul Boian Spanţov, descoperit în secțiunea C de la Hârşovatell, ne relevă că această populație preistorică se ocupa în principal cu activitatea de creștere a animalelor, în special a bovinelor și a ovicaprinelor. Vârstele de sacrificare în cazul bovinelor ilustrează o exploatare mixtă (atât pentru carne, cât și pentru producția de lapte), în timp ce ovicaprinele erau exploatate mai ales pentru producția de lapte. Porcul este exploatat prin excelență pentru carne și grăsime, iar studiul vârstelor de abataj ne arată consumul unei cărni de foarte bună calitate, dat fiind faptul că cele mai multe animale sacrificate au sub 12 luni,

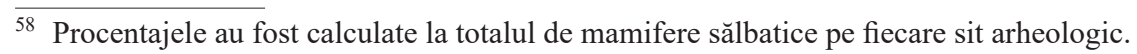


ele neatingând încă maximul ponderal. Câinele are și o funcție alimentară, pe lângă cea de paznic al turmelor, locuințelor și companion al omului, dar importanța sa în cadrul paleoeconomiei animaliere nu este atât de mare având în vedere talia sa redusă. Vânătoarea avea un rol secundar de suplimentare a cantității de carne, dar şi de îndepărtare a acțiunii prădătoare a unor animale sălbatice. Se vânau în special mistrețul și cerbul.

O comparație cu alte situri Boian Spanțov care au beneficiat de studii arheozoologice (Căscioarele, Izvoarele, Lăceni-Măgura, Radovanu și Tangâru) ne arată că o trăsătură comună a acestora o reprezintă activitatea de creștere a animalelor, în primul rând a bovinelor. Locul secund este disputat între ovicaprine și porcine care se găsesc la mare distanță de bovine. Vânatoarea are o importanță redusă, locul întâi ca pondere avându-1 cerbul în majoritatea așezărilor, mai puțin la Hârşova-tell unde mistrețul depășește cerbul.

Așezarea de la Hârșova, prin prisma suprafețelor studiate din diferite contexte culturale, Boian Spanțov cu SC/ pP și SC (spre baza tell-ului) și Gumelniţa A2 cu SB (spre partea superioară a tell-ului) a permis surprinderea unei evoluții a paleoeconomiei animaliere. Astfel se observă că primele comunități Boian Spanțov practicau cu succes creșterea cornutelor mari și mici, iar vânatul avea o pondere extrem de redusă, pentru ca în Gumelnița A2 să observăm că aceste populații creșteau în principal ovicaprine și porcine, iar vânatul crește ca importanță, existând un interes mult mai mare pentru acesta în condițiile unei sedentarizări accentuate a acestor populații. Probabil că sedentarizarea comunităților Boian și apoi a celor Gumelnița determină o schimbare în paleoeconomia animalieră a acestora. Astfel observăm o trecere de la exploatarea bovinelor la cea a porcinelor, în timp ce ponderea ovicaprinelor rămâne relativ constantă, în condițiile în care o populație mult mai stabilă devine mult mai interesată şi de exploatarea mediului înconjurător dacă avem în vedere creșterea frecvenței vânatului în Gumelniţa A2. Nu trebuie omis nici aportul pescuitului și al culesului moluştelor mai ales în sezonul cald care probabil era extrem de important ${ }^{59}$.

\section{Mulțumiri}

Ne exprimăm și pe această cale recunoștiința noastră către Dragomir-Nicolae Popovici, care din păcate nu mai este printre noi, coordonatorul cercetărilor arheologice de la Hârşova-tell care întotdeauna ne-a sprijinit necondiționat în demersul nostru științtific. Nu aş vrea să-i omit aici pe prietenii francezi, Bernard Randoin și Yannick Rialland (care ne-a părăsit și el de curând) care ne-au facilitat fomarea profesională în Franța. Nu în ultimul rând doresc să îmi exprim gratitudinea către întregul colectiv de cercetare de la Hârșova.

Acest articol a fost realizat în cadrul unui grant finanțat de către Ministerul Cercetării și Inovării, CCDI UEFISCDI, proiectul PN-III-P1-1.2-PCCDI-2017-0686 (PATCULT\#RO), din cadrul PNCDI III.

\section{BIBLIOGRAFIE}

Balasse et al. 2016

Balasse, M., Evin, A., Tornero, C., Radu, V., Fiorillo, D., Popovici, D., Andreescu, R., Dobney, K, Cucchi, T., Bălășescu, A., Wild domestic and feral? Investigating the status of suids in the Romanian Gumelnița (5th mil. cal BC) with biogeochemistry and geometric morphometrics, Journal of Anthropological Archaeology, 42, 2016, 24-36.

Balasse et al. 2017a

Balasse, M., Bălăşescu, A., Tornero, C., Fremondeau, D., Hovsepyan, R., Gillis, R., Popovici, D.N., Investigating the scale of herding in Chalcolithic pastoral communities settled by the Danube river in the $5^{\text {th }}$ millennium BC: a case study at Borduşani-Popină and Hârşova-tell (Romania), Quaternary International, 436, Part B, 2017, 29-40.

Balasse et al. 2017b

Balasse, M., Tresset, A., Bălăşescu, A., Blaise, E., Tornero, C., Gandois, H., Fiorillo, D., Nyerges, E.A., Frémondeau, D., Banffy, E. Ivanova, M., Animal Board Invited Review: Sheep birth distribution in past herds: a review for prehistoric Europe $\left(6^{\text {th }}\right.$ - $3^{\text {th }}$ millennium BC), Animal Journal, 11, 2017, 2229-2236.

\footnotetext{
$\overline{59}$ Bréhard et al. 2014.
} 
Balasse et al. 2018

Barone 1986

Bălășescu 2014

Bălăşescu, Radu 2004

Bălăşescu, Moise, Radu 2005

Bălăşescu, Radu, Moise 2005

Bălăşescu, Moise, Radu 2006

Boesneck, Mulller, Teichert 1964

Bolomey 1981

Bréhard, Bălăşescu 2012

Bréhard et al. 2014

Clutton-Brock et al. 1990

Cronica 1983-2017

Desse-Berset, Radu 1996

Desse-Berset, Radu 2006

Driesch 1976

Ducos 1968
Balasse, M., Cucchi, T., Evin, A., Bălăşescu, A., Frémondeau D., HorardHerbin, M.-P., Wild game or farm animal? Tracking human-pig relationship in ancient times through stable isotope analysis, în Stépanoff, C., Vigne, J.D. (eds.), Hybrid Communities: Biosocial Approaches to Domestication and Other Trans-species Relationships, Routledge Studies in Anthropology, 81-96.

Barone, R., Anatomie comparée des mammifères domestiques, t. 1, Ostéologie, Editura Vigit Frères: Paris, 1986.

Bălăşescu, A., Arheozoologia neo-eneoliticului de pe Valea Teleormanului, Muzeul Național de Istorie a României, Colecția Muzeului Naţional, Seria Cercetări Puridisciplinare, XIV, Editura Mega, Cluj Napoca, 2014.

Bălăşescu, A., Radu, V., Omul şi animalele. Strategii şi resurse la comunităţile Hamangia şi Boian, Biblioteca Muzeului Naţional, Seria Cercetări Pluridisciplinare, 9, Editura Cetatea de Scaun: Târgovişte, 2004.

Bălăşescu, A., Moise, D., Radu, V., The palaeoeconomy of Gumelniţa communities on the territory of Romania, CCDJ, XXII, 2005, 167-206.

Bălăşescu, A., Radu, V., Moise, D., Omul si mediul animal în mileniile VII- IV la Dunărea de Jos, Biblioteca Muzeului Naţional, Seria Cercetări Pluridisciplinare, 11, Editura Cetatea de Scaun, Târgovişte, 2005.

Bălăşescu, A., Moise, D., Radu, V., Une utilisation des bovins pour la traction pendant le Chalcolithique en Roumanie ?, în P. Petrequin, R.-M., Arbogast, A.-M., Petrequin, S., van Willingen, M., Bailly (eds.), Premiers chariots, premiers araires. La diffusion de la traction animale en Europe pendant les $I V^{e}$ et III ${ }^{e}$ millénaires avant notre ère, CRA Monographies 29, CNRS éditions: Paris, 2006, 269-273.

Boessneck, J., Mulller, H., Teichert, M., Osteologische Unterscheinungsmerkmle zwischen Schaf (Ovis aries) und Ziege (Capra hircus), Kuhn Archiv, 78, 1964, 1-129.

Bolomey, A., Contribuţie la cunoaşterea economiei animale a culturii Boian în lumina materialelor de la Căscioarele, jud. Călăraşi, CA, 5, 1981, 169-193.

Bréhard, S., Bălăşescu, A., What's behind the tell phenomenon? An archaeozoological approach of Eneolithic sites in Romania, Journal of Archaeological Science, 39, 2012, 3167-3183.

Bréhard, S., Radu, V., Martin, A., Pauline H., Popovici, P., Bălăşescu, A., Food supply strategies in the Romanian Eneolithic: sheep/goat husbandry and fishing activities from Hârşova tell and Borduşani-Popină ( $5^{\text {th }}$ millennium $\mathrm{BC}$ ), European Journal of Archaeology, 17 (3), 2014, 407-433.

Clouton Brok, J., Dennis-Bryan, K., Armitage, P.L., Jewell, P.A., Osteology of the Soay sheep, Bulletin British Museum (Natural History), vol. 56, n. 1, 1990, 1-56.

Cronica cercetărilor arheologice din România, 1983-2012. Rapoarte preliminare de cercetare arheologică, http://cronica.cimec.ro/CercetariARH.asp, accesat 20.03.2020.

Desse-Berset, N., Radu, V., Stratégies d'échantillonnage et d'exploitation des restes osseux de poissons pour une approche paléoenvironnementale et paléoéconomique: l'exemple d'Hârşova Roumanie, (Néolithique finalChalcolithique), în Langouet, L. (ed.), Actes du Colloque d'Archéométrie 1995, Périgueux (Dordogne, France), Revue d'Archéométrie, supplément, 1996, 181-186.

Desse-Berset, N., Radu, V., Les premiers pêcheurs d'Hârșova (Dobrogea, Roumanie), CA, XIII, 2006, 393-407.

Driesch, A. von den, Guide to the measurement of animal bones from archaeological sites, Peabody Museum Bulletin, 1, Harvard University, 1976, 137.

Ducos, P., L'origine des animaux domestiques en Palestine, Publications de l'Institut de Préhistoire de l'Université de Bordeaux, Mémoire no 6, Delmas: Bordeaux, 1968. 
Evin et al. 2015

Forest 1997

Frantz et al. 2016

Frantz et al. 2019

Gál, Kessler 2002

Galbenu 1962

Galbenu 1966

Galbenu 1979

Grant 1982

Halstead, Collins, Isaakidou 2003

Haşotti 1989
Evin, A., Girdland Flink, L., Bălășescu, A., Popovici, D., Andreescu, R., Bailey, D., Mirea, P., Lazăr, C., Boroneanț, A., Bonsall, C., Strand Vidarsdottir, U., Brehard, S., Tresset, A., Cucchi, T., Larson, G., Dobney, K., Unravelling the complexity of domestication: A case study using morphometrics and ancient DNA analyses of archaeological pigs from Romania, Philosophical Transactions B, vol. 370, issue 1660, 2015, 20130616, 7 .

Forest, V., Donnees biologiques et donnees zootechniques anciennes. Essai de mise en equivalence, Revue de Medecine Veterinaire, 148, 12, 1997, 951-958.

Frantz, L.A.F., Mullin, V.E., Pionnier-Capitan, M., Lebrasseur O., Ollivier, M., Perri A., Linderholm, A., Mattiangeli V., Teasdale M.D., Dimopoulos E.A., Tresset A., Duffraisse M., McCormick F., Bartosiewicz, L., Gál, E., Nyerges E.A., Sablin M.V., Bréhard, S., Mashkour M., Bălășescu A., Gillet, B., Hughes S., Chassaing, O., Hitte, C., Vigne, J.-D., Dobney, K., Hänni, C., Bradley, D.G., Larson G., Genomic and archaeological evidence suggest a dual origin of domestic dogs, Science, Vol. 352, Issue 6290, 2016, 1228-1231.

Frantz, L.A.F., Haile J., Lin A.T., Scheu A., Geörg C., Benecke N., Alexander, M., Linderholm, A., Mullin, V.E., Daly K.G., Battista, V.M., Price, M., Gron, K.J., Alexandri P., Arbogast, R.M., Arbuckle, B., Bălăşescu, A., Barnett, R., Bartosiewicz, L., Baryshnikov, G., Bonsall, C., Borić D., Boroneanţ, A., Bulatović J., Çakirlar, C., Carretero, J.-M., Chapman J., Church M., Crooijmans R., Cupere, B., Detry C., Dimitrijevic, V., Dumitraşcu, V., Plessis, L., Edwards, C.J., Erek, C.M., Erim-Özdoğan, A., Ervynck, A., Fulgione, D., Gligor, M., Götherström, A., Gourichon, L., Groenen, M.A.M., Helmer, D., Hongo, H., Horwitz L.K., Irving-Pease E.K., Lebrasseur, O., Lesur, J., Malone, C., Manaseryan N., Marciniak, A., Martlew, H., Mashkour, M., Matthews, R., Motuzaite Matuzeviciute, G., Maziar S., E. Meijaard, McGovern T., Megens H.-J., Miller, R., Mohaseb, A.F., Orschiedt, J., Orton, D., Papathanasiou A., Pearson, M.P., Pinhasi, R., Radmanović, D., Ricaut F.-X., Richards, M., Sabin, R., Sarti, L., Schier, W., Sheikhi, W., Stephan, E., Stewart, J.R., Stoddart S., Tagliacozzo, A., Tasić, N., Trantalidou, K., Tresset, A., Valdiosera, C., Hurk, Y., Poucke, S., Vigne, J.-D., Yanevich, A., Zeeb-Lanz, A., Triantafyllidis, A., Thomas, M., Gilbert, P., Schibler, J., Rowley-Conwy, P., Zeder, M., Peters, J., Cucchi T., Bradley D.G., Dobney, K., Burger, J., Evin, A., Girdland-Flink, L., Larson, G., Ancient pigs reveal a near-complete genomic turnover following their introduction to Europe, Proceedings of the National Academy of Sciences of the United States of America, 116 (35), 2019, 17231-17238.

Gál, E., Kessler, E., Bird remains from the Eneolithic and Iron Age site Borduşani-Popină and Eneolithic site Hârşova (Southeast Romania), Acta zoologica cracoviensia, 45 (special issue), 2002, 253-262.

Galbenu, D., Aşezarea neolitică de la Hârşova, SCIV, 13, 2, 1962, 285-306.

Galbenu, D., 1966, Nouvelles données concernant le dèbut de la civilisation de Gumelnița de Dobrogea, Dacia N.S., X, 1966, 321-325.

Galbenu, D., Săpături în tell-ul de la Hârşova, jud. Constanţa, CA, III, 1979, 3-8.

Grant, A., The use of tooth wear as a guide to the age of domestic ungulates, in B. Wilson, C. Grigson, S. Payne (eds), Ageing and sexing animal bones from archaeological sites, British Archaeological Reports, British Series, 109, 1982, 91-108.

Halstead, P., Collins, P., Isaakidou, V., Sorting the sheep from the goats: morphological distinctions between the mandibles and mandibular teeth of adult Ovis and Capra, Journal of Archaeological Science, 29, (5), 2003, 545554.

Haşotti, P., Consideraţii cu privire la cultura Gumelniţa în Dobrogea, Pontica, XXI-XXII, 1989, 13-29. 
Haşotti 1997

Haşotti, Popovici 1992

Helmer 2000

Horard-Herbin 1997

Larson et al. 2007

Lazăr, Mărgărit, Bălăşescu 2016

Le Bailly et al. 2006

Moise 2000

Necrasov 1959

Necrasov 1973

Necrasov, Ghiorghiu 1970

Ollivier et al. 2013

Ollivier et al. 2016

Ollivier et al. 2018
Haşotti, P., Epoca neolitică în Dobrogea, Bibliotheca Tomitana, Constanţa, 1997.

Haşotti, P., Popovici, D., Cultura Cernavodă I în contextul descoperirilor de la Hârşova, Pontica, XXV, 1992, 15-44.

Helmer, D., Discrimination des genres Ovis et Capra a l'aide des prémolaires inférieures 3 et 4 et interprétation des âges d'abattage: l'exemple de Dikili Tash (Grèce), Ibex Journal of Mountain Ecology 5 - Anthropozoologica, 31, 2000, 29-38.

Horard-Herbin, M.-P., Le village celtique des Arènes à Levroux. L'élevage et

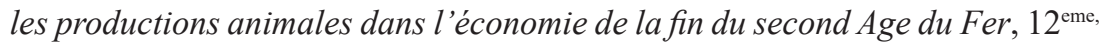
supplément à la Revue du Centre de la France, Levroux 4, 1997.

Larson, G., Albarella, U., Dobney, K., Rowley-Conwy, P., Schibler, P., Tresset, A., Vigne, J.-D., Edwards, C., Schlumbaum, A., Dinu, A., Bălăşescu A., A., Dolman, G., Tagliacozzo G., Manaseryan, N., Miracle P., Van WijngaardenBakker, L., Masseti M., Bradley, D.G., Cooper A., Ancient DNA, pig domestication, and the spread of the Neolithic into Europe, Proceeding of the National Academy of Sciences of the United States of America, 104, n. 39, 2007, 15276-15281.

Lazăr, C., Mărgărit, M., Bălăşescu, A., Dogs, jaws and other stories: two symbolic objects made of dog mandibles from Sultana - Malu Roșu tell settlement (Southeastern Europe), Journal of Field Archaeology, 41, 1, 2016, 101-117.

Le Bailly, M., Bălăşescu, A., Popovici, D., Barbin, V., Paicheler, J.-C., Nouvelle approche taphonomique des coprolithes du Tell d'Hârşova (Roumanie): Contribution de la cathodoluminescence, Compte Rendus Palevol, 5, 2006, 919-925.

Moise, D., Etude du matériel ostéologique appartenant aux mammifères découvert dans le Complexe 521 (la zone ménagère) sur le tell néo-énéolithique de Hârşova (dép. de Constantza), CA, XI (1), 2000, 84-111.

Necrasov, O., Etude de la faune de la station néolithique de Tangâru, Dacia, 3, 1959, 102-111.

Necrasov, O., Studiul resturilor de faună din aşezarea neolitică de la Radovanu, jud. Ilfov, $M C A, 10,1973,39-46$.

Necrasov O. et Gheorghiu S., 1970, Studiul resturilor de faună din aşezarea neolitică de la Izvoarele, $M C A, 9,91-96$.

Ollivier, M., Tresset, A., Hitte, C., Petit, C., Hughes, S., Gillet, B., Duffraisse, M., Pionnier-Capitan, M., Lagoutte, L., Arbogast, R.-M., Bălășescu, A., Boroneant, A., Mashkour, M., Vigne, J.-D., Hanni, C., Evidence of Coat Color Variation Sheds New Light on Ancient Canids, PLoS ONE, 8(10): e75110, 2013.

Ollivier, M., Tresset, A., Bastian, F., Lagoutte, L., Axelsson, E., Arendt, M.-L., Balasescu, A., Marshour, M., Pionnier-Capitan, M., Sablin, M. V., Salanova, L., Vigne, J.-D., Hitte, C., Hänni, C.,' Amy2B copy number variation reveals starch diet adaptation in European ancient dogs, Royal Society Open Science, 3, (11), 160449, 2016, 1-9.

Ollivier, M., Tresset, A., Frantz, L.A.F., Bréhard, S., Bălășescu, A., Mashkour, M., Boroneanț, A., Pionnier-Capitan, M., Lebrasseur, O., Arbogast, R.-M., Bartosiewicz, L., Debue, K., Rabinovich, R., Sablin, M.V., Larson, G., Hänni, C., Hitte, C., Vigne, J.-D., Dogs accompanied humans during the Neolithic expansion into Europe, Biology letters, 14 (10), 2018, 1-4. 
Ottoni et al. 2017

Payne 1973

Payne 1985

Popovici, Haşotti 1992

Popovici, Randoin, Rialland 2001

Popovici et al. 1992

Popovici et al. 2000

Popovici et al. 2002

Popovici et al. 2012

Popovici et al. 2014

Popovici et al. 2016

Popovici et al. 2019

Prummel, Frisch 1986

Radu 2000

Radu 2011
Ottoni, C., Neer, W., Cupere, B., Daligault, J., Guimaraes, S., Peters J., Spassov, N., Prendergast, M., Boivin, N., Morales-Muñiz, A., Bălășescu, A., Becker, C., Benecke N., Boroneant,, A., Buitenhuis, H., Chahoud, J., Crowther, A., Llorente, L., Manaseryan, N., Monchot, H., Onar, V., Osypińska, M., Putelat, O., Morales, E.M.Q., Studer, J., Wierer, U., Decorte, R., Grange T., Geigl E.M., The palaeogenetics of cat dispersal in the ancient world, Nature Ecology \& Evolution, 1, 0139, 2017, 1-7.

Payne, S., Kill-off patterns in sheep and goats: the mandibles from Asvan Kale, Anatolian Studies, 23, 1973, 281-303.

Payne, S., Morphological distinction between the mandibular teeth of young sheep, Ovis and goats, Capra, Journal of Archaeological Science, 12, 1985, 139-147.

Popovici, D., Haşotti, P., Considerations about the Synchronism of the Cernavodă I Culture, Pontica, XXI-XXII, (1988-1989), 1992, 291-299.

Popovici, D., Randoin, B., Rialland, Y., Le tell néolithique et chalcolithique d'Hârşova (Roumanie), în Guilaine, J., (ed.), Communautés villageoises du Proche-Orient à l'Atlantique (8000-2000 avant notre ère), Séminaire du Collège de France, Edition Errance, Paris, 2001, 119-152.

Popovici, D., Haşotti, P., Galbenu, D., Nicolae, C., Cercetările arheologice din tell-ul de la Hârşova, jud. Constanţa, 1988, CA, IX, 1992, 8-11.

Popovici, D., Randoin, B., Rialland, Y., Voinea, V., Vlad, F., Bem, C., Bem, C., Haită, G., Les recherches archéologiques du tell de Hârşova (dép. de Constanţa) 1997-1998, CA, XI (1), 2000, 13-123.

Popovici, D., Bălășescu, A., Haită, C., Radu, V., Tomescu, A.M.F., Tomescu, I., Cercetarea arheologică pluridisciplinară. Concepte, metode și tehnici, Biblioteca Muzeului Național, Seria Cercetări Pluridisciplinare, III, Editura Cetatea de Scaun, Târgoviște, 2002.

Popovici, D., Randoin, B., Haşotti, P., Rialland, Y., Voinea, V., Ilie, A., Vlad, F., Parnic, V., Bălăşescu, A., Haită, C., Radu V., Collaboration franco-roumaine sur le site archéologique du tell énéolithique d'Hârşova (dep. Constanţa), în Recherches croisées en Dobrogea, Bucharest, 17-18 mai 2012, Supplément de GeoEcoMarina, 18, 2012, 41.

Popovici, D.N., Randoin, B., Cernău, I., Cernea, C., Ilie, A., Haită, C., Bălășescu, A., Radu, V., Mărgărit, M., Nițu, L, R., Hovsepyan, Programul de colaborare româno-francez de la Hârșova-tell, jud. Constanța. Campania 2013, $C A$, XXI, 2014, 25-54.

Popovici, D.N., Randoin, B., Ilie, A., Haită, C., Bălășescu, A., Radu, V., Mărgărit, M., Niţu, L, Programul de colaborare româno-francez de la Hârșovatell, jud. Constanța. Campania 2016, CA, XXIII, 2016, 17-47.

Popovici, D.N., Haită, C., Ilie, A., Bălășescu, A., Radu, V., Man and environment in the Lower Danube Valley. New data from the Boian Culture at Hârșova-tell (Constanța County), comunicare susținută în cadrul Colocviului Internaţional Les sociétés préhistoriques dans l'espace carpato-danubien: environnements, systemes techniques, interactions, 24-27 juin 2019, Bucarest.

Prummel, W., Frisch, H.-J., A guide for distinction of species, sex and body side in bones of sheep and goat, Journal of Archaeological Science, 13, 1986, 567-577.

Radu, V., Sur la durée d'utilisation d'une zone de rejets ménagers appartenant à la culture Gumelnita A2 du tell d'Hârșova. Etude archéologique préliminaire, $C A$, XI (1), 2000, 75-83.

Radu, V., Le Néolithique de la Roumanie Méridionale: Exploitation des ressources aquatiques dans les cultures Boian et Gumelniţa, Editions Universitaires Européennes: Sarrebruck, 2011. 
Radu et al. 2016

Randoin, Popovici, Rialland 2000

Sárkány-Kiss, Boloș 1996

Schmid 1972

Știrbu 1980

Udrescu Bejenaru, Tarcan 1999
Radu, V., Popovici, D.N., Cernea, C., Cernău, I., Bălăşescu, A., Harvesting molluscs in the Eneolithic: a study of freshwater bivalve accumulations from the tell settlements of Bordușani-Popină and Hârșova (Romania, $5^{\text {th }}$ millennium BC), Environment archaeology, 21 (4), 2016, 334-350.

Randoin, B., Popovici, D., Rialland, Y., Metoda de săpătură şi înregistrarea datelor stratigrafice într-un sit pluristratificat: tell-ul neo-eneolitic de la Hârşova, CA, XI (1), 2000, 199-234.

Sárkány-Kiss, A., Boloș, F., Malacological aspects of the archaeological excavations in the Neo-Eneolithic settlement at Hârşova, oral presentation sustained at International Conference ,"Vivre au bord du Danube il y a 6500 ans". Bucureşti, 13-15 November, 1996.

Schmid, E., Atlas of Animal Bones, for Prehistorians, Archaeologists and Quaternary Geologists, Elsevier Publishing Company, 1972.

Ştirbu, M., Paleofauna neolitică de la Radovanu şi unele aspecte ale ocupaţiilor locuitorilor din cultura Boian, Analele Ştiinţifice ale Universităţii ,,Al. I. Cuza” (s.n.), t. 26, s. II, a. Biologie, 1980, 107-108.

Udrescu, M., Bejenaru, L., Tarcan C., Introducere în arheozoologie, Editura Corson, Iaşi, 1999.

\section{LIST OF ILLUSTRATIONS}

Figure 1. La position géographique du site de Hârșova-tell (1) et des autres établissements Boian Spanțov qui présentent des études d'archéozoologie dans le sud-est de la Roumanie (2 - Căscioarele; 3 - Radovanu; 4 Tangâru; 5 - Izvoarele; 6 - Lăceni-Măgura).

Figure 2. La répartition numérique et en pourcentage des restes de faune découverte dans la section C de Hârşovatell (Boian Spanțov).

Figure 3. La distribution numérique et en pourcentage des restes de mammifères découverte dans la section $\mathrm{C}$ de Hârşova-tell (Boian Spanțov).

Figure 4. Séparation biométrique des deux espèces bovines (Bos taurus - Bt et Bos primgenius - Bp) sur différents éléments anatomiques. Les mesures sont en millimètres et leurs codes sont d'après von den Driesch.

Figure 5. Séparation biométrique des deux espèces porcines (Sus domesticus - Sd; Sus scrofa - Ss; Sus domesticus/ Sus scrofa $-\mathrm{Sd} / \mathrm{Ss}$ ) sur différents éléments anatomiques. Les mesures sont en millimètres et leurs codes sont d'après von den Driesch (1976).

Figure 6. Répartition en pourcentage du nombre de restes (NR) et du nombre minimal d'individus (NMI) des mammiféres découverts dans la section C de Hârşova-tell (Boian Spanțov). Légende: cervidés - cerf et chevreuil; autres animaux sauvages - cheval, renard, blaireau, chat sauvage, loutre, lièvre.

Figure 7. Les comparaisons des pourcentages du nombre de restes de mammifères découverts dans différents contextes culturels et sections archéologiques de Hârşova-tell. Légende: cervidés - cerf et chevreuil; carnivores loup, renard, blaireau, martre, loutre, chat sauvage; autres espèces - l'aurochs, cheval, castor et lièvre.

Figure 8. Comparaisons des pourcentages des mammifères domestiques et sauvages découvertes dans différents sites Boian, phase Spanțov.

Figure 9. Comparaisons des pourcentages de restes de mammifères domestiques découvertes dans différents sites de Boian, phase Spanţov.

Figure 10. Comparaisons des pourcentages des restes de mammifères sauvages découverts dans différents sites de Boian, phase Spanţov. Légende: carnivores - loup, renard, blaireau, putois, loutre, chat sauvage, ours; cervidés cerf et chevreuil; autres espèces - castor et cheval.

Annexe 1. (biométrie). Les mesures sont en millimètres et leurs codes sont d'après von den Driesch. 
Annexe 2. Répartition numérique des restes fauniques par espèce et par éléments anatomiques découverts à Hârșova-tell (section C).

Planche I. 1. Bos taurus, processus cornulaire femelle (norme nucale); 2. Bos taurus, astragale gauche (norme médiale) avec de traces de coupe; 3. Capra hircus, processus cornulaire (norme médiale); 4. Capra hircus, processus cornulaire droit avec de traces de coupe sur la base (norme médiale); 5. Sus domesticus, mandibule gauche (a) et droite (b et c - norme crânienne); 6. Sus domesticus, mandibule droite (a - norme latérale) et gauche (b et c - norme linguale); 7. Canis familiaris, neurocrâne (norme basale) avec de traces de coupe et de brûlure; 8 . Canis familiaris, neurocrâne (norme latérale) avec de traces de coupe et de brûlure.

Planche II. 1. Cervus elaphus, neurocrâne avec de traces de coupe à la base de la corne (norme médiale); 2. Cervus elaphus, neurocrâne avec de traces de coupe à la base de la corne (norme dorsale); 3. Cervus elaphus, tibia proximal (gauche) et tibia distal (droite) (norme dorsale); 4. Sus scrofa, humérus distal (norme crânienne); 5. Sus scrofa, coxal gauche (norme latérale); 6. Sus scrofa, calcaneus droits (norme médiale); 7. Vulpes vulpes, humérus (gauche), radius (milieu), tibia (droite) (norme dorsale); 8. Felis silvestris, humérus proximal (norme médiale).

Planche III. 1. Meles meles, tibia proximal gauche (norme médiale); 2. Lutra lutra, fémur droit avec traces de décarnisations (norme caudale); 3. Lepus europaeus, mandibule droite (norme latérale); 4. Lepus europaeus, humérus distal (gauche) et radius proximal (droit) (norme dorsale).

ADRIAN BĂLĂȘESCU, Institutul de Arheologie „Vasile Pârvan”, Academia Română, București a.balasescu@gmail.com 
Anexa 1 (biometrie).

Măsurătorile sunt în milimetri și codurile acestora sunt după von den Driesch ${ }^{59}$.

\section{Bos taurus (vita)}

\begin{tabular}{|l|c|c|}
\hline Proces cornular & 759 & 760 \\
\hline 44 & 154 & 141 \\
\hline 45 & 53,5 & 49,2 \\
\hline 46 & 46,5 & 40,1 \\
\hline 47 & 253 & \\
\hline
\end{tabular}

\begin{tabular}{|l|c|c|c|c|c|c|c|c|c|c|c|c|}
\hline Mandibulă & 1463 & 65 & 1857 & 1465 & 1605 & 1239 & 11 & 185 & $\mathrm{n}$ & $\min$ & $\max$ & med \\
\hline 7 & 131 & & & & & & & & 1 & 131 & 131 & 131 \\
\hline 9 & 48 & 49,7 & & & & & & & 2 & 48 & 49,7 & 48,9 \\
\hline 8 & 81 & & & & & & & & 1 & 81 & 81 & 81 \\
\hline $10 \mathrm{~L}$ & 37 & & 38 & 38 & 35,5 & 39 & 39 & 36 & 7 & 35,5 & 39 & 37,5 \\
\hline $10 \mathrm{~B}$ & 15,5 & & 16 & 13 & 14 & 17 & 15,7 & 12,2 & 7 & 12,2 & 17 & 14,8 \\
\hline
\end{tabular}

\begin{tabular}{|l|c|c|c|c|c|c|c|c|}
\hline Maxila & 437 & 239 & 719 & 224 & $\mathrm{n}$ & $\min$ & $\max$ & $\operatorname{med}$ \\
\hline 20 & 80,5 & 76,5 & & & 2 & 76,5 & 80,5 & 78,5 \\
\hline L M3 & 28,2 & & 32,7 & 32,5 & 3 & 28,2 & 32,7 & 31,1 \\
\hline 1 M3 & 19,2 & & 22,9 & 20 & 3 & 19,2 & 22,9 & 20,7 \\
\hline
\end{tabular}

\begin{tabular}{|l|c|c|c|c|c|c|c|c|c|}
\hline Scapula & 525 & 646 & 115 & 767 & 727 & $\mathrm{n}$ & $\min$ & $\max$ & med \\
\hline SLC & 62,2 & 50,2 & & 49,8 & & 3 & 49,8 & 62,2 & 54,1 \\
\hline GLP & 76,7 & 63,3 & 61 & & & 3 & 61 & 76,7 & 67 \\
\hline LG & 67 & 57,7 & 54,5 & 58,7 & & 4 & 54,5 & 67 & 59,5 \\
\hline BG & 57 & 48,9 & 43,5 & 46,3 & 43 & 5 & 43 & 57 & 47,7 \\
\hline
\end{tabular}

\begin{tabular}{|l|c|c|c|c|c|c|c|c|c|c|}
\hline Humerus & 591 & 706 & 1241 & 1382 & 567 & 1172 & $\mathrm{n}$ & $\min$ & $\max$ & med \\
\hline Bd & 77,2 & 84,6 & 94 & 88,5 & 78,5 & & 5 & 77,2 & 94 & 84,6 \\
\hline BT & 68,7 & 69,5 & 86,5 & 79,5 & 70,4 & 83 & 6 & 68,7 & 86,5 & 76,3 \\
\hline Dd & 67 & 72,5 & & & & & 2 & 67 & 72,5 & 69,8 \\
\hline
\end{tabular}

\begin{tabular}{|l|c|c|c|c|c|c|c|c|c|c|c|c|c|}
\hline Radius & 1243 & 439 & 462 & 264 & 459 & 839 & 1386 & 1682 & 1174 & $\mathrm{n}$ & $\min$ & $\max$ & $\operatorname{med}$ \\
\hline Bp & 79 & 72,9 & 83,1 & & & & & & & 3 & 72,9 & 83,1 & 78,3 \\
\hline BFp & 72 & 65 & 75,7 & & & & & & & 3 & 65 & 75,7 & 70,9 \\
\hline Dp & 38,5 & 40,5 & 40,4 & 38,1 & & & & & & 4 & 38,1 & 40,5 & 39,4 \\
\hline Bd & & & & & 71,4 & 71,2 & 68 & 85 & 74 & 5 & 68 & 85 & 73,9 \\
\hline BFd & & & & & 61,6 & 63,3 & 64 & 73 & 66,5 & 5 & 61,6 & 73 & 65,7 \\
\hline Dd & & & & & 40,3 & 40,1 & & & & 2 & 40,1 & 40,3 & 40,2 \\
\hline
\end{tabular}

\begin{tabular}{|l|c|}
\hline Ulna & 523 \\
\hline LO & 123 \\
\hline DPA & 79,3 \\
\hline SDO & 59,5 \\
\hline
\end{tabular}

\begin{tabular}{|l|c|}
\hline Coxal & 709 \\
\hline LA & 61,5 \\
\hline LAR & 50,2 \\
\hline
\end{tabular}

\begin{tabular}{|l|c|c|c|c|c|c|c|c|}
\hline Femur & 414 & 226 & 570 & 577 & $\mathrm{n}$ & $\min$ & $\max$ & med \\
\hline DC & 43,5 & 45 & 46,5 & 44,3 & 4 & 43,5 & 46,5 & 44,8 \\
\hline
\end{tabular}

\begin{tabular}{|l|c|c|c|c|c|c|c|}
\hline Tibie & 438 & 377 & 590 & $\mathrm{n}$ & $\min$ & $\max$ & $\operatorname{med}$ \\
\hline Bd & 62,8 & 59,5 & & 2 & 59,5 & 62,8 & 61,2 \\
\hline Dd & 47,5 & 47 & 46,5 & 3 & 46,5 & 47,5 & 47 \\
\hline
\end{tabular}

\begin{tabular}{|l|c|c|c|c|c|c|c|c|c|}
\hline Calcaneu & 2 & 579 & 1245 & 117 & 1722 & $\mathrm{n}$ & $\min$ & $\max$ & med \\
\hline GL & 142 & 120 & 121 & 128 & 148 & 5 & 120 & 148 & 132 \\
\hline GB & 50,5 & 38,2 & & & & 2 & 38,2 & 50,5 & 44,4 \\
\hline
\end{tabular}

\footnotetext{
${ }^{59}$ Driesch 1976.
} 
(continuare)

\begin{tabular}{|l|c|c|c|c|c|c|c|c|c|c|c|c|c|c|c|c|}
\hline Astragal & 1175 & 1245 & 1630 & 1660 & 1897 & 1475 & 1656 & 4 & 658 & 797 & 79 & 1474 & $\mathrm{n}$ & $\min$ & $\max$ & $\operatorname{med}$ \\
\hline GLl & 66 & 67 & 71 & 61 & 69 & 67 & 67 & 67 & 63,2 & 69,4 & 64 & 67 & 12 & 61 & 71 & 66,6 \\
\hline GLm & 62 & 62 & 67 & 57,5 & 64 & 62,3 & 63 & 61,5 & 59,5 & 65,2 & 59 & 63 & 12 & 57,5 & 67 & 62,2 \\
\hline Dl & 37 & 36,5 & 40,5 & 35 & 38 & 39 & 38,5 & 38 & 36 & 39,2 & 35,6 & & 11 & 35 & 40,5 & 37,6 \\
\hline Dm & 37,2 & 36 & 41 & 36 & 37,5 & 40 & 39 & 38 & 36 & 39,8 & & & 10 & 36 & 41 & 38,1 \\
\hline Bd & 37 & 42 & 45 & 40,5 & 44 & 45,5 & 41,5 & 42,4 & 41,2 & 46,3 & & 41,5 & 11 & 37 & 46,3 & 42,4 \\
\hline
\end{tabular}

\begin{tabular}{|l|c|c|c|c|c|c|c|c|c|c|c|c|c|c|c|}
\hline Centrotars & 1176 & 1422 & 1609 & 1689 & 1332 & 1477 & 1899 & 1 & 151 & 228 & 399 & $\mathrm{n}$ & $\min$ & $\max$ & $\operatorname{med}$ \\
\hline BG & 52 & 55,5 & 61 & 57 & 51,8 & 59 & 55,5 & 54,2 & 55,8 & 52,8 & 60,1 & 11 & 51,8 & 61 & 55,9 \\
\hline DAP & 50,5 & 56 & 58 & 56,5 & 50 & 56 & 53 & 50,3 & 53,7 & 53,5 & 52 & 11 & 50 & 58 & 53,6 \\
\hline
\end{tabular}

\begin{tabular}{|l|c|c|c|c|c|c|c|c|c|c|c|c|c|c|c|c|c|c|c|}
\hline Metacarpian & 1357 & 1387 & 1683 & 1331 & 787 & 368 & 300 & 578 & 608 & 789 & 837 & 1684 & 1435 & 1893 & 47 & $\mathrm{n}$ & $\min$ & $\max$ & $\operatorname{med}$ \\
\hline $\mathrm{Bp}$ & 61 & & 58 & 54 & 52,2 & 59,9 & 55,5 & 57 & & & & & & & & 7 & 52,2 & 61 & 56,8 \\
\hline $\mathrm{Dp}$ & 38 & 34 & 34 & 34 & 31 & 39,2 & 30,5 & 34 & 31,3 & 31,6 & 31,9 & & & & & 11 & 30,5 & 39,2 & 33,6 \\
\hline $\mathrm{Bd}$ & & & & & & & & & & & & 65,5 & 60,5 & 57 & 64,7 & 4 & 57 & 65,5 & 61,9 \\
\hline $\mathrm{Dd}$ & & & & & & & & & & & & & 31,5 & 31,7 & 32,8 & 3 & 31,5 & 32,8 & 32 \\
\hline
\end{tabular}

\begin{tabular}{|l|c|c|c|c|c|c|c|c|c|c|c|c|}
\hline Metatarsian & 1478 & 1690 & 1928 & 1248 & 1361 & 461 & 391 & 263 & $\mathrm{n}$ & $\min$ & $\max$ & med \\
\hline $\mathrm{Bp}$ & & & & & & 50,1 & 48,5 & 51,2 & 3 & 48,5 & 51,2 & 49,9 \\
\hline $\mathrm{Dp}$ & & & & & & 47,9 & & & 1 & 47,9 & 47,9 & 47,9 \\
\hline $\mathrm{Bd}$ & 62 & 61,4 & 55 & 52 & 54,6 & & & & 5 & 52 & 62 & 57 \\
\hline $\mathrm{Dd}$ & 33,3 & 34 & 33 & 30,5 & 31,5 & & & & 5 & 30,5 & 34 & 32,5 \\
\hline
\end{tabular}

\begin{tabular}{|l|c|c|c|c|c|c|c|c|c|c|c|c|}
\hline Falanga 1 ant & 1928 & 1851 & 1763 & 1693 & 1692 & 1394 & 1592 & 1437 & $\mathrm{n}$ & $\min$ & $\max$ & med \\
\hline GL & 56 & 53,6 & 58,5 & 60,5 & 57,3 & 59,5 & 60,5 & 63 & 8 & 53,6 & 63 & 58,6 \\
\hline Bp & 28 & 30,5 & 32 & 34 & 29 & 31 & 29 & 30 & 8 & 28 & 34 & 30,4 \\
\hline SD & 22,5 & 25 & 26 & 30 & 25 & 23 & 24 & 25 & 8 & 22,5 & 30 & 25,1 \\
\hline Bd & 26 & 26,5 & 30,5 & 32,5 & 26,5 & 27,5 & 28 & 30 & 8 & 26 & 32,5 & 28,4 \\
\hline
\end{tabular}

\begin{tabular}{|l|c|c|c|c|c|c|c|c|c|c|c|c|c|c|c|}
\hline Falanga 1 post & 1262 & 1861 & 1438 & 1633 & 1480 & 1839 & 1593 & 1219 & 1661 & 1458 & 1798 & $\mathrm{n}$ & $\min$ & $\max$ & $\mathrm{med}$ \\
\hline GL & 61 & 62 & 60 & 60 & 60 & 63 & 63 & 62 & 63,5 & 64 & 64 & 11 & 60 & 64 & 62 \\
\hline Bp & 26,5 & 28,5 & 28 & 29,5 & 27,5 & 33 & 32 & 28 & 31 & 33 & & 10 & 26,5 & 33 & 29,7 \\
\hline SD & 22 & 24 & 23 & 24,5 & 23 & 27,5 & 27 & 23 & 25 & & 24,5 & 10 & 22 & 27,5 & 24,4 \\
\hline Bd & 25,2 & 28 & 26,5 & 27,5 & 26,5 & 27,5 & 32 & 26 & 29,5 & & 29,5 & 10 & 25,2 & 32 & 27,8 \\
\hline
\end{tabular}

\begin{tabular}{|l|c|c|c|c|c|c|c|c|}
\hline Falanga 2 ant & 1662 & 1250 & 1913 & 1221 & $\mathrm{n}$ & $\min$ & $\max$ & $\operatorname{med}$ \\
\hline GL & 42,5 & 40 & 38 & 40 & 4 & 38 & 42,5 & 40,1 \\
\hline Bp & 32 & 28 & 27,5 & 29 & 4 & 27,5 & 32 & 29,1 \\
\hline SD & 26,5 & 22 & 22 & 22,5 & 4 & 22 & 26,5 & 23,3 \\
\hline Bd & 28 & 24 & 23,5 & 24,5 & 4 & 23,5 & 28 & 25 \\
\hline
\end{tabular}

\begin{tabular}{|l|c|c|}
\hline Falanga 2 post & 1745 & 1395 \\
\hline GL & 45,5 & 43 \\
\hline Bp & 37 & 35,5 \\
\hline SD & 29,5 & 29 \\
\hline Bd & 31,5 & 30 \\
\hline
\end{tabular}

\begin{tabular}{|c|c|c|c|c|c|c|c|c|c|c|c|c|c|c|c|}
\hline Falanga 3 & 5 & 53 & 232 & 390 & 400 & 265 & \begin{tabular}{|l|l|}
681 \\
\end{tabular} & 708 & 725 & \begin{tabular}{|l|}
726 \\
\end{tabular} & 401 & $\mathrm{n}$ & $\min$ & $\max$ & med \\
\hline DLS & 84,7 & 68,2 & 68 & 69,2 & 76 & 83,8 & 67 & 64,4 & 63 & 67,5 & & 10 & 63 & 84,7 & 71,2 \\
\hline \multicolumn{8}{|r|}{$; 7$} & 49,3 & 48,5 & 53,3 & & 10 & 48,5 & 64,1 & 55,6 \\
\hline MBS & 29,2 & 22,1 & 25,5 & 25 & 24,7 & 28,5 & 27,5 & 24,6 & 19,3 & 23,4 & 24 & 11 & 19,3 & 29,2 & 24,9 \\
\hline Axis & 1670 & 60 & 517 & $\mathrm{n}$ & $\min$ & $\max$ & med & & & & & & & & \\
\hline BFcr & 81 & 104 & 79,7 & 3 & 79,7 & 104 & 88,3 & & & & & & & & \\
\hline SBV & 50 & & & 1 & 50 & 50 & 50 & & & & & & & & \\
\hline
\end{tabular}




\section{Ovis aries (oaia)}

\begin{tabular}{|l|c|c|c|c|c|c|c|c|c|c|}
\hline Scapulã & 1496 & 1494 & 1423 & 290 & 485 & 624 & $\mathrm{n}$ & $\min$ & $\max$ & med \\
\hline SLC & 17,5 & 19,4 & 18,5 & 20,3 & 23 & 19,5 & 6 & 17,5 & 23 & 19,7 \\
\hline GLP & & 33,2 & 32,5 & 32,8 & 34 & 34 & 5 & 32,5 & 34 & 33,3 \\
\hline LG & & 27 & 25,8 & 26 & 28 & 27,2 & 5 & 25,8 & 28 & 26,8 \\
\hline BG & & 21 & 21 & 21,7 & 23,3 & 19,3 & 5 & 19,3 & 23,3 & 21,3 \\
\hline
\end{tabular}

\begin{tabular}{|l|c|c|c|c|c|c|c|}
\hline Humerus & 86 & 1424 & 1206 & $\mathrm{n}$ & $\min$ & $\max$ & med \\
\hline Bd & 30,7 & 25,8 & 24,5 & 3 & 24,5 & 30,7 & 27 \\
\hline BT & 29 & 24 & 23 & 3 & 23 & 29 & 25,3 \\
\hline Dd & 25,2 & & & 1 & 25,2 & 25,2 & 25,2 \\
\hline
\end{tabular}

\begin{tabular}{|l|c|c|c|c|c|c|c|c|c|c|}
\hline Radius & 1855 & 1370 & 1753 & 691 & 1557 & 1196 & $\mathrm{n}$ & $\min$ & $\max$ & $\operatorname{med}$ \\
\hline Bp & 28 & 30,5 & 31 & 28,4 & & & 4 & 28 & 31 & 29,5 \\
\hline BFp & 27 & 27,5 & 27 & 25,6 & & & 4 & 25,6 & 27,5 & 26,8 \\
\hline Dp & & & & 14,7 & & & 1 & 14,7 & 14,7 & 14,7 \\
\hline Bd & & & & & 27 & 26 & 2 & 26 & 27 & 26,5 \\
\hline BFd & & & & & 22,5 & 22 & 2 & 22 & 22,5 & 22,3 \\
\hline
\end{tabular}

\begin{tabular}{|l|c|c|c|c|c|c|c|c|c|c|}
\hline Metacarpian & 1319 & 1801 & 1559 & 1497 & 1496 & 1487 & $\mathrm{n}$ & $\min$ & $\max$ & med \\
\hline $\mathrm{Bp}$ & 21 & 22 & 23,6 & 22 & 21,3 & 22 & 6 & 21 & 23,6 & 22 \\
\hline $\mathrm{Dp}$ & 15 & 16,5 & 16,5 & 15 & 16 & 15,5 & 6 & 15 & 16,5 & 15,8 \\
\hline
\end{tabular}

\begin{tabular}{|l|c|c|c|c|c|c|c|c|c|c|}
\hline Tibie & 429 & 628 & 692 & 748 & 777 & 778 & $\mathrm{n}$ & $\min$ & $\max$ & $\operatorname{med}$ \\
\hline $\mathrm{Bd}$ & 22,6 & 24,1 & 23,3 & 24,6 & 25,5 & 24,5 & 6 & 22,6 & 25,5 & 24,1 \\
\hline $\mathrm{Dd}$ & 18 & 19,5 & 19,1 & 18,7 & 20,2 & 19,5 & 6 & 18 & 20,2 & 19,2 \\
\hline
\end{tabular}

\begin{tabular}{|l|c|}
\hline Astragal & 534 \\
\hline GLl & 26,7 \\
\hline GLm & 24,2 \\
\hline Dl & 14,6 \\
\hline Dm & 15,4 \\
\hline Bd & 17,6 \\
\hline Talia (Teichert) & 606 \\
\hline
\end{tabular}

\begin{tabular}{|l|c|c|}
\hline Metatars & 486 & 820 \\
\hline Bd & 24,8 & 22 \\
\hline Dd & 16,4 & 14,3 \\
\hline
\end{tabular}

\section{Capra hircus (capra)}

\begin{tabular}{|l|c|c|c|c|c|c|c|}
\hline Proces cornular & 703 & 803 & 79 & $\mathrm{n}$ & $\min$ & $\max$ & med \\
\hline 40 & 93 & 98 & 83 & 4 & 40 & 98 & 78,5 \\
\hline 41 & 34,3 & 37,5 & 32,5 & 4 & 32,5 & 41 & 36,3 \\
\hline 42 & 24,4 & 20 & 21 & 4 & 20 & 42 & 26,9 \\
\hline 43 & 180 & 219 & & 3 & 43 & 219 & 147 \\
\hline $\operatorname{sex}$ & $\mathrm{F}$ & $\mathrm{F}$ & & & & & \\
\hline
\end{tabular}

\begin{tabular}{|l|c|}
\hline Scapulã & 1934 \\
\hline SLC & 18 \\
\hline GLP & 29 \\
\hline LG & 23 \\
\hline
\end{tabular}

\begin{tabular}{|l|c|c|}
\hline Radius & 747 & 818 \\
\hline Bp & 29,7 & 28,6 \\
\hline BFp & 28,2 & 27,8 \\
\hline Dp & 14,7 & 14,9 \\
\hline
\end{tabular}

\begin{tabular}{|l|c|c|c|c|c|c|c|c|}
\hline Metacarpian & 1558 & 530 & 690 & 1885 & $\mathrm{n}$ & $\min$ & $\max$ & med \\
\hline GL & 108 & & & & 1 & 108 & 108 & 108 \\
\hline Bp & 25 & 25,3 & & & 2 & 25 & 25,3 & 25,2 \\
\hline Dp & 17,5 & 17,2 & & & 2 & 17,2 & 17,5 & 17,4 \\
\hline SD & 16,3 & & & & 1 & 16,3 & 16,3 & 16,3 \\
\hline Bd & 22 & & 26,5 & 25 & 3 & 22 & 26,5 & 24,5 \\
\hline Dd & 17 & & 15,4 & 15 & 3 & 15 & 17 & 15,8 \\
\hline Talia (Schram) & 618 & & & & 1 & 618 & 618 & 618 \\
\hline
\end{tabular}

\begin{tabular}{|l|c|}
\hline Astragal & 406 \\
\hline GLl & 27,9 \\
\hline GLm & 26,8 \\
\hline Dl & 15,7 \\
\hline Dm & 15,6 \\
\hline Bd & 18,1 \\
\hline
\end{tabular}

\begin{tabular}{|c|c|c|}
\hline Humerus & 165 & 1611 \\
\hline $\mathrm{Bd}$ & 29,2 & 31 \\
\hline BT & 28 & 30 \\
\hline Dd & 25,5 & \\
\hline Femur & 430 & \\
\hline Bp & 38,3 & \\
\hline $\mathrm{DC}$ & 18,9 & \\
\hline
\end{tabular}


Sus domesticus (porc)

\begin{tabular}{|l|c|c|c|c|c|c|c|c|c|}
\hline Scapula & 1941 & 1225 & 1713 & 1374 & 1449 & $\mathrm{n}$ & $\min$ & $\max$ & med \\
\hline SLC & 24 & 21,5 & 23 & 23 & & 4 & 21,5 & 24 & 22,9 \\
\hline GLP & 34,5 & 33 & 39 & 35,5 & 36 & 5 & 33 & 39 & 35,6 \\
\hline LG & 30 & 28 & 31,5 & 30 & 30,5 & 5 & 28 & 31,5 & 30 \\
\hline BG & 23 & 22 & 25 & 27 & 22,5 & 5 & 22 & 27 & 23,9 \\
\hline
\end{tabular}

\begin{tabular}{|l|c|c|}
\hline Humerus & 1812 & 163 \\
\hline Bd & 36 & 37,8 \\
\hline BT & 28,6 & 28 \\
\hline
\end{tabular}

\begin{tabular}{|l|c|c|}
\hline Tibie & 1268 & 366 \\
\hline $\mathrm{Bd}$ & 28 & 27,1 \\
\hline $\mathrm{Dd}$ & 23 & 26 \\
\hline
\end{tabular}

\begin{tabular}{|l|c|}
\hline Radius & 136 \\
\hline $\mathrm{Bp}$ & 26,2 \\
\hline $\mathrm{Dp}$ & 18,5 \\
\hline
\end{tabular}

\begin{tabular}{|l|c|}
\hline Metacarpian IV & 1571 \\
\hline GL & 71 \\
\hline Bp & 15,5 \\
\hline SD & 10 \\
\hline Dd & 14 \\
\hline
\end{tabular}

\begin{tabular}{|c|c|}
\hline Talia (Teichert) & 718 \\
\hline
\end{tabular}

\begin{tabular}{|l|c|}
\hline Atlas & 274 \\
\hline GB & 73,9 \\
\hline GL & 44 \\
\hline BFcr & 56 \\
\hline BFcd & 46,2 \\
\hline GLF & 40,5 \\
\hline H & 45,5 \\
\hline
\end{tabular}

\begin{tabular}{|l|c|c|}
\hline Coxal & 1274 & 1417 \\
\hline LA & 38 & 27,5 \\
\hline
\end{tabular}

\section{Canis familiaris (câine)}

\begin{tabular}{|l|c|c|c|c|c|c|c|}
\hline Mandibula & 180 & 296 & 192 & $\mathrm{n}$ & $\min$ & $\max$ & med \\
\hline 7 & 27,5 & & & 1 & 27,5 & 27,5 & 27,5 \\
\hline 13 L & 18,5 & 16,5 & 20,2 & 3 & 16,5 & 20,2 & 18,4 \\
\hline $13 \mathrm{~B}$ & 7,1 & 8,4 & 7,5 & 3 & 7,1 & 8,4 & 7,67 \\
\hline 14 & 17,5 & 16,2 & & 2 & 16,2 & 17,5 & 16,9 \\
\hline
\end{tabular}

\begin{tabular}{|l|c|c|c|c|c|c|c|}
\hline Maxila & 639 & 334 & 618 & $\mathrm{n}$ & $\min$ & $\max$ & med \\
\hline 16 & 15,3 & 16 & 14 & 3 & 14 & 16 & 15,1 \\
\hline $18 \mathrm{~L}$ & 17,2 & 16 & 15,5 & 3 & 15,5 & 17,2 & 16,2 \\
\hline $18 \mathrm{~GB}$ & 9,4 & 9,2 & 8 & 3 & 8 & 9,4 & 8,87 \\
\hline $18 \mathrm{~B}$ & 6,2 & 6 & 6,5 & 3 & 6 & 6,5 & 6,23 \\
\hline $20 \mathrm{~L}$ & 11,3 & & & 1 & 11,3 & 11,3 & 11,3 \\
\hline $20 \mathrm{~B}$ & 14 & & & 1 & 14 & 14 & 14 \\
\hline $21 \mathrm{~L}$ & 6 & & & 1 & 6 & 6 & 6 \\
\hline $21 \mathrm{~B}$ & 8,2 & & & 1 & 8,2 & 8,2 & 8,2 \\
\hline
\end{tabular}

\begin{tabular}{|l|c|}
\hline Scapula & 616 \\
\hline SLC & 19,2 \\
\hline GLP & 24 \\
\hline LG & 20,5 \\
\hline BG & 13,8 \\
\hline
\end{tabular}

\begin{tabular}{|l|c|}
\hline Ulna & 155 \\
\hline SDO & 13,5 \\
\hline DPA & 16 \\
\hline BPC & 9,9 \\
\hline
\end{tabular}

\begin{tabular}{|l|c|}
\hline Falanga II & 270 \\
\hline GL & 32,6 \\
\hline Bp & 22 \\
\hline SD & 17,5 \\
\hline Bd & 18 \\
\hline
\end{tabular}

\begin{tabular}{|l|c|}
\hline Falanga 1 & 480 \\
\hline GL & 40,9 \\
\hline $\mathrm{Bp}$ & 22 \\
\hline $\mathrm{SD}$ & 17,3 \\
\hline $\mathrm{Bd}$ & 21 \\
\hline
\end{tabular}

\begin{tabular}{|c|c|c|}
\hline Radius & 316 & 315 \\
\hline $\mathrm{Bp}$ & 15,4 & \\
\hline Dp & 9,8 & \\
\hline $\mathrm{Bd}$ & & 20 \\
\hline Dd & & 11,4 \\
\hline Tibie & 320 & 409 \\
\hline $\mathrm{Bp}$ & 30 & \\
\hline $\mathrm{Bd}$ & & 17 \\
\hline $\mathrm{Dd}$ & & 12,1 \\
\hline
\end{tabular}

\begin{tabular}{|l|c|}
\hline Femur & 319 \\
\hline $\mathrm{Bp}$ & 32 \\
\hline $\mathrm{DC}$ & 16,5 \\
\hline
\end{tabular}




\section{Bos primigenius (bour)}

\begin{tabular}{|l|c|}
\hline Metacarpian & 167 \\
\hline $\mathrm{Bd}$ & 70 \\
\hline $\mathrm{Dd}$ & 36 \\
\hline
\end{tabular}

\begin{tabular}{|l|c|}
\hline Falanga 2 & 578 \\
\hline $\mathrm{GL}$ & 52 \\
\hline $\mathrm{Bp}$ & 40,5 \\
\hline $\mathrm{SD}$ & 31,5 \\
\hline $\mathrm{Bd}$ & 32,5 \\
\hline
\end{tabular}

\section{Sus scrofa (mistreț)}

\begin{tabular}{|l|c|c|}
\hline Scapula & 112 & 597 \\
\hline SLC & 30,5 & 35 \\
\hline GLP & 49 & 50 \\
\hline LG & 41 & 40,5 \\
\hline BG & 35 & 35 \\
\hline
\end{tabular}

\begin{tabular}{|l|c|c|c|c|c|c|c|c|}
\hline Humerus & 501 & 832 & 700 & 982 & $\mathrm{n}$ & $\min$ & $\max$ & med \\
\hline Bd & 55,8 & 50,4 & 50 & 55,5 & 4 & 50 & 55,8 & 52,9 \\
\hline BT & 44,2 & 38,3 & 37 & 40 & 4 & 37 & 44,2 & 39,9 \\
\hline Dd & 55 & 49,5 & & & 2 & 49,5 & 55 & 52,3 \\
\hline
\end{tabular}

\begin{tabular}{|l|c|c|c|c|c|c|c|}
\hline Radius & 108 & 136 & 367 & $\mathrm{n}$ & $\min$ & $\max$ & med \\
\hline $\mathrm{Bp}$ & 36,5 & 26,2 & 36,5 & 3 & 26,2 & 36,5 & 33,1 \\
\hline $\mathrm{Dp}$ & 26 & 18,5 & 25,7 & 3 & 18,5 & 26 & 23,4 \\
\hline
\end{tabular}

\begin{tabular}{|l|c|}
\hline Ulna & 253 \\
\hline LO & 82 \\
\hline DPA & 46,5 \\
\hline SDO & 56 \\
\hline
\end{tabular}

\begin{tabular}{|l|c|c|c|c|c|c|c|c|c|c|}
\hline Coxal & 1003 & 1245 & 1487 & 478 & 500 & 699 & $\mathrm{n}$ & $\min$ & $\max$ & med \\
\hline LA & 41 & 43 & 40 & 46,4 & 46,2 & 45,5 & 6 & 40 & 46,4 & 43,7 \\
\hline
\end{tabular}

\begin{tabular}{|l|c|c|c|c|c|c|c|c|}
\hline Calcaneu & 502 & 631 & 740 & 1924 & $\mathrm{n}$ & $\min$ & $\max$ & med \\
\hline GL & 110 & 102 & 110 & 109 & 4 & 102 & 110 & 108 \\
\hline BG & 29 & 29,3 & 31 & & 3 & 29 & 31 & 29,8 \\
\hline Talia (Teichert) & 1053 & 979 & 1051 & 1044 & 4 & 979 & 1053 & 1032 \\
\hline
\end{tabular}

\begin{tabular}{|l|c|}
\hline Astragal & 15 \\
\hline GLl & 52 \\
\hline GLm & 45 \\
\hline Dl & 27,5 \\
\hline Dm & 31 \\
\hline Bd & 28,8 \\
\hline
\end{tabular}

\begin{tabular}{|l|l|}
\hline Talia (Teichert) & 954 \\
\hline
\end{tabular}

\section{Cervus elaphus (cerb)}

\begin{tabular}{|l|c|c|}
\hline Scapula & 1470 & 179 \\
\hline SLC & 40 & 41 \\
\hline GLP & 63 & 66 \\
\hline LG & 48 & 50 \\
\hline BG & 41 & 49 \\
\hline
\end{tabular}

\begin{tabular}{|c|c|}
\hline Metatarsian & 392 \\
\hline $\mathrm{Bd}$ & 75,5 \\
\hline Dd & 43,5 \\
\hline Falanga 3 & 450 \\
\hline DLS & 93 \\
\hline $\mathrm{Ld}$ & 71,5 \\
\hline MBS & 34,7 \\
\hline
\end{tabular}

\begin{tabular}{|l|c|c|c|}
\hline Tibie & 1530 & 1793 & Sus sp. \\
\hline Bd & 40,7 & 41 & 34 \\
\hline Dd & 35,3 & 33,5 & 29 \\
\hline
\end{tabular}

\begin{tabular}{|l|c|c|}
\hline Humerus & 458 & 75 \\
\hline $\mathrm{Bd}$ & 60,9 & 56,5 \\
\hline $\mathrm{BT}$ & 53,2 & 55 \\
\hline $\mathrm{Dd}$ & 56,7 & 59,5 \\
\hline
\end{tabular}




\begin{tabular}{|l|c|c|}
\hline Radius & 24 & 902 \\
\hline $\mathrm{Bp}$ & 63,5 & 69 \\
\hline $\mathrm{BFp}$ & 58 & 65 \\
\hline $\mathrm{Dp}$ & 34 & 37,5 \\
\hline
\end{tabular}

\begin{tabular}{|l|c|c|}
\hline Femur & 74 & 455 \\
\hline Bp & 74,8 & \\
\hline DC & 31,5 & \\
\hline Bd & & 70 \\
\hline Dd & & 98,3 \\
\hline
\end{tabular}

\begin{tabular}{|l|c|c|c|c|c|c|c|c|c|}
\hline Tibie & 838 & 1297 & 1752 & 191 & 639 & $\mathrm{n}$ & $\min$ & $\max$ & med \\
\hline $\mathrm{Bp}$ & 82,4 & 89 & & & & 2 & 82,4 & 89 & 85,7 \\
\hline $\mathrm{Dp}$ & 70,8 & & & & & 1 & 70,8 & 70,8 & 70,8 \\
\hline $\mathrm{Bd}$ & & & 56 & 52 & 49,2 & 3 & 49,2 & 56 & 52,4 \\
\hline $\mathrm{Dd}$ & & & 42 & 47,5 & 42,2 & 3 & 42 & 47,5 & 43,9 \\
\hline
\end{tabular}

\begin{tabular}{|l|c|}
\hline Metatarsian & 1821 \\
\hline Bd & 49 \\
\hline Dd & 32 \\
\hline
\end{tabular}

\begin{tabular}{|l|c|c|c|c|c|c|c|}
\hline Falanga 1 & 193 & 310 & 1639 & $\mathrm{n}$ & $\min$ & $\max$ & med \\
\hline GL & 58,2 & & & 1 & 58,2 & 58,2 & 58,2 \\
\hline Bp & 22 & & & 1 & 22 & 22 & 22 \\
\hline SD & 17,8 & 18 & 18,2 & 3 & 17,8 & 18,2 & 18 \\
\hline Bd & 21,8 & 22,5 & 21,5 & 3 & 21,5 & 22,5 & 21,9 \\
\hline
\end{tabular}

\begin{tabular}{|l|c|c|}
\hline Falanga 2 & 169 & 355 \\
\hline GL & 42 & 49,4 \\
\hline $\mathrm{Bp}$ & 21 & 25,7 \\
\hline $\mathrm{SD}$ & 14,3 & 17,2 \\
\hline $\mathrm{Bd}$ & 17,5 & 21,5 \\
\hline
\end{tabular}

\begin{tabular}{|l|c|}
\hline Atlas & 73 \\
\hline GB & 115 \\
\hline GL & 106 \\
\hline BFcr & 79 \\
\hline BFcd & 70 \\
\hline GLF & 84 \\
\hline H & 54,5 \\
\hline
\end{tabular}

Capreolus capreolus (căprior)

\begin{tabular}{|l|r|}
\hline Tibie & 697 \\
\hline Bd & 21,7 \\
\hline DAPd & 17,9 \\
\hline
\end{tabular}

Vulpes vulpes (vulpea)

\begin{tabular}{|l|c|}
\hline Humerus & 729 \\
\hline $\mathrm{Bd}$ & 21,1 \\
\hline $\mathrm{Dd}$ & 16,2 \\
\hline \multicolumn{2}{|l}{} \\
\hline Radius & 1541 \\
\hline $\mathrm{Bd}$ & 14,9 \\
\hline $\mathrm{Dd}$ & 7,9 \\
\hline
\end{tabular}

Meles meles (bursuc)

\begin{tabular}{|l|c|}
\hline Femur & 937 \\
\hline $\mathrm{Bd}$ & 21,8 \\
\hline $\mathrm{Dd}$ & 18 \\
\hline
\end{tabular}

\begin{tabular}{|l|c|}
\hline Metacarpian & 783 \\
\hline Bd & 50 \\
\hline Dd & 32 \\
\hline
\end{tabular}

\begin{tabular}{|l|c|c|}
\hline Centrotars & 245 & 656 \\
\hline BG & 51,5 & 44,3 \\
\hline DAP & 47,2 & 42,5 \\
\hline
\end{tabular}

\begin{tabular}{|l|l|}
\hline Calcaneu & 192 \\
\hline GL & 127 \\
\hline
\end{tabular}

GL

\begin{tabular}{|l|c|c|}
\hline Falanga 3 & 418 & 168 \\
\hline DLS & 49,6 & 58,7 \\
\hline Ld & 46,2 & 45,2 \\
\hline MBS & 13,7 & 18,2 \\
\hline
\end{tabular}

\begin{tabular}{|l|c|c|}
\hline Falanga 1 & 407 & 772 \\
\hline GL & 35,5 & 44,9 \\
\hline Bp & 11,2 & 13,2 \\
\hline SD & 8,2 & 10,7 \\
\hline Bd & 10 & 13 \\
\hline
\end{tabular}

\begin{tabular}{|l|l|}
\hline Tibie & 1621 \\
\hline Bp & 22,7 \\
\hline Dp & 24,7 \\
\hline
\end{tabular}

\begin{tabular}{|l|c|}
\hline Tibie & 1039 \\
\hline $\mathrm{Bp}$ & 28,3 \\
\hline $\mathrm{Dp}$ & 26 \\
\hline
\end{tabular}




\section{Lutra lutra (vidra)}

\begin{tabular}{|l|c|}
\hline Femur & 987 \\
\hline $\mathrm{Bp}$ & 24 \\
\hline $\mathrm{DC}$ & 10,8 \\
\hline
\end{tabular}

Lepus europaeus (iepurele de câmp)

\begin{tabular}{|l|c|}
\hline Humerus & 419 \\
\hline $\mathrm{Bd}$ & 13,1 \\
\hline $\mathrm{Dd}$ & 10,2 \\
\hline
\end{tabular}

\begin{tabular}{|l|c|c|}
\hline Radius & 776 & 901 \\
\hline $\mathrm{Bp}$ & 9,1 & \\
\hline $\mathrm{Dp}$ & 7,3 & \\
\hline $\mathrm{Bd}$ & & 10,8 \\
\hline $\mathrm{BFd}$ & & 9,2 \\
\hline $\mathrm{Dd}$ & & 6,9 \\
\hline
\end{tabular}

\begin{tabular}{|l|c|c|}
\hline Coxal & 295 & 494 \\
\hline GL & 90,2 & 86,5 \\
\hline LA & 12,9 & 12 \\
\hline SB & 6,9 & 7,6 \\
\hline SH & 11,1 & 12,6 \\
\hline LFO & & 20,4 \\
\hline
\end{tabular}


Anexa 2.

Repartiția numerică a resturilor faunistice pe specii și elemente anatomice descoperite la Hârșova-tell (secțiunea C).

\begin{tabular}{|c|c|c|c|c|c|c|c|c|c|c|c|c|c|c|c|c|c|c|c|c|}
\hline 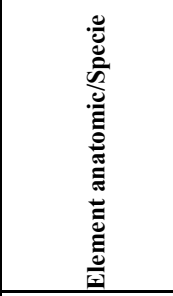 & $\begin{array}{l}\hat{\Xi} \\
\mathbf{s} \\
\tilde{\Xi} \\
0 \\
0\end{array}$ & 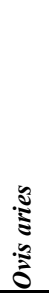 & 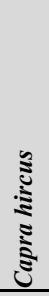 & 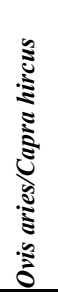 & 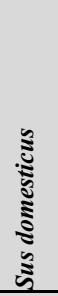 & : & 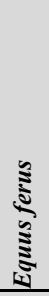 & 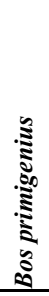 & 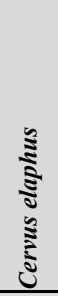 & 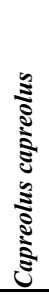 & 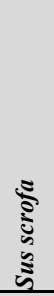 & $\begin{array}{l}\tilde{\Xi} \\
\vdots \\
\vdots \\
\vdots \\
\vdots \\
\vdots \\
\Xi\end{array}$ & 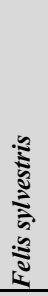 & 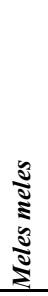 & 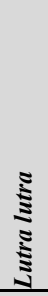 & 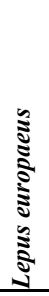 & 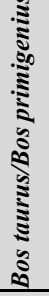 & 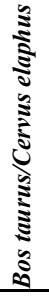 & 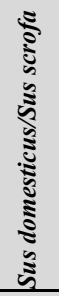 & 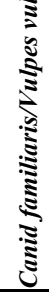 \\
\hline corn & & & & & & & & & 12 & & & & & & & & & & & \\
\hline proces cornular & 4 & 1 & 8 & & & & & & & & & & & & & & & & & \\
\hline neurocraniu & 37 & 1 & 2 & 1 & 11 & 2 & & 2 & 3 & & 1 & & & & & & & & 17 & \\
\hline viscerocraniu & 10 & & & 1 & 1 & 1 & & & & & & & & & & & & & $\longrightarrow$ & \\
\hline maxilar & 11 & & & 3 & 4 & 6 & & 2 & & & 3 & & & & & & & & 5 & \\
\hline dinții sup & 20 & & & 6 & 2 & & & & 5 & & 1 & & & & & & & & & \\
\hline mandibulã & 36 & & & 29 & 19 & 14 & & 2 & 5 & & 2 & & & & & 1 & & 1 & 10 & \\
\hline dinții inferiori & 38 & & & 12 & 4 & 2 & & & 1 & & 2 & & & & & & & & 1 & \\
\hline atlas & 6 & 2 & 1 & 2 & 2 & 2 & & 1 & 1 & & 3 & & & & & & & & 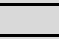 & \\
\hline axis & 4 & 1 & & 1 & 2 & 2 & & & & & 2 & & & & & & 1 & & & 1 \\
\hline vert. cervicale & 16 & & & 5 & 3 & 3 & & 1 & 4 & & & & & & & & & 1 & 3 & \\
\hline vert. toracale & 29 & & & 11 & 1 & 1 & & & 3 & & 6 & & & & & & & 1 & 6 & \\
\hline vert. lombare & 27 & & & 11 & 1 & 1 & & 1 & 1 & & 2 & & & & & & & 1 & 9 & 2 \\
\hline vert. sacrale & 5 & & & & 1 & & & & & & 1 & & & & & & & & & \\
\hline vert. caudale & 3 & & & & & & & & & & & & & & & & & & & \\
\hline scapulã & 32 & 8 & 1 & 16 & 16 & 3 & & 3 & 3 & & 2 & & 1 & & & & & & 12 & \\
\hline humerus & 18 & 6 & 2 & 32 & 13 & & & 5 & 9 & & 11 & 1 & 1 & & & 1 & & 1 & 3 & \\
\hline radius & 29 & 16 & 4 & 28 & 6 & 11 & & 5 & 5 & & 5 & 1 & & & & 3 & & 3 & 6 & \\
\hline ulnã & 13 & & & 4 & 7 & 8 & & & 3 & & 5 & & & & & 1 & & & 5 & \\
\hline carpiene & 6 & & & & 1 & & & & 1 & & 4 & & & & & & & & 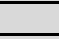 & \\
\hline metacarpiene & 28 & 8 & 5 & 11 & 6 & 4 & & 1 & 5 & & 3 & & & & & 1 & & & 1 & \\
\hline coxal & 62 & 1 & 2 & 29 & 4 & 3 & & 1 & 3 & & 10 & 1 & & & & 2 & & 1 & 11 & \\
\hline femur & 40 & 1 & 1 & 24 & 4 & 4 & & 1 & 3 & & 5 & & & 1 & 1 & & & 1 & 9 & \\
\hline patella & 1 & & & & 1 & & & & 2 & & 1 & & & & & & & & & \\
\hline tibie & 41 & 9 & 1 & 35 & 3 & 6 & 1 & 2 & 5 & 1 & 11 & 1 & & 1 & & 1 & & & 7 & \\
\hline fibulã & & & & & & & & & & & & & & & & & & & 3 & \\
\hline tarsiene & 16 & & & & & & & & 4 & & 1 & & & & & & & & & \\
\hline calcaneu & 14 & & & 1 & 1 & & & 2 & 4 & & 4 & & & & & & & & 5 & \\
\hline astragal & 16 & 3 & 1 & 2 & & & & & 3 & & 1 & & & & & & & & & \\
\hline metatarsiene & 21 & 12 & 1 & 15 & 5 & 2 & & & 4 & & 7 & & & & & 2 & & & 6 & \\
\hline metapodii & 10 & & 1 & 5 & 5 & 2 & & & 2 & & 6 & & & & & & & & 3 & \\
\hline falanga I & 40 & & & 3 & 4 & & & & 6 & 2 & 4 & & & & & & & & 1 & \\
\hline falanga II & 13 & & & & 2 & & & 1 & 4 & & 6 & & & & & & & & 4 & \\
\hline falanga III & 17 & & & & 1 & & & 2 & 4 & & & & & & & & & & & \\
\hline Total & 663 & 69 & 30 & 287 & 130 & 77 & 1 & 32 & 105 & 3 & 109 & 4 & 2 & 2 & 1 & 12 & 1 & 10 & 127 & 3 \\
\hline
\end{tabular}




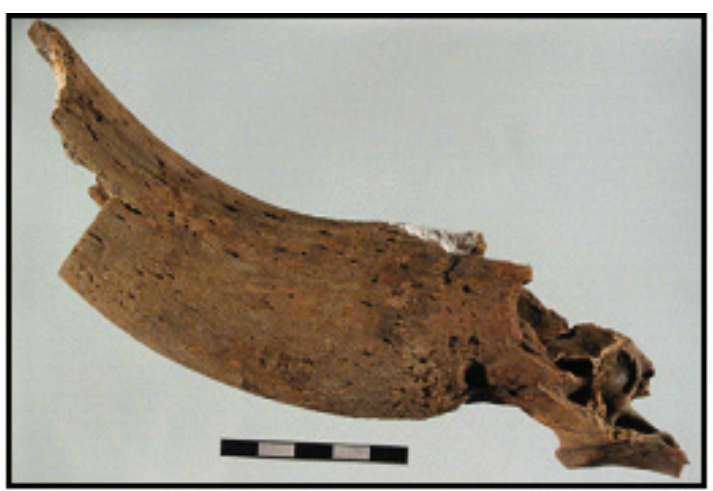

1.

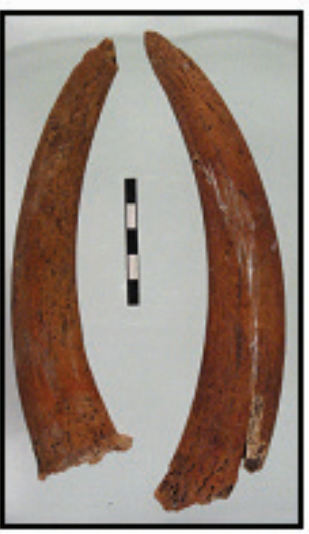

3.

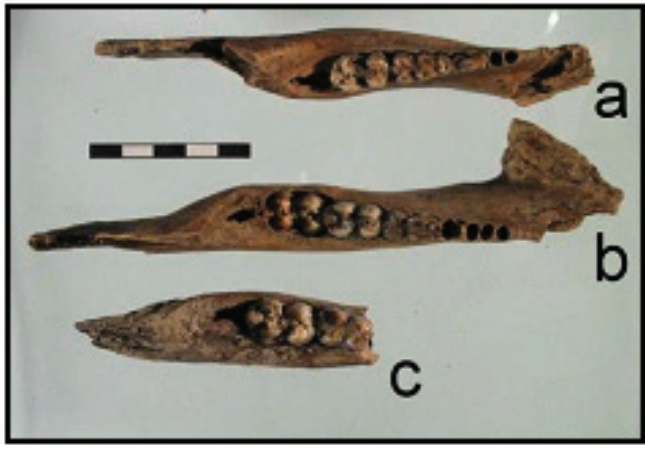

5.

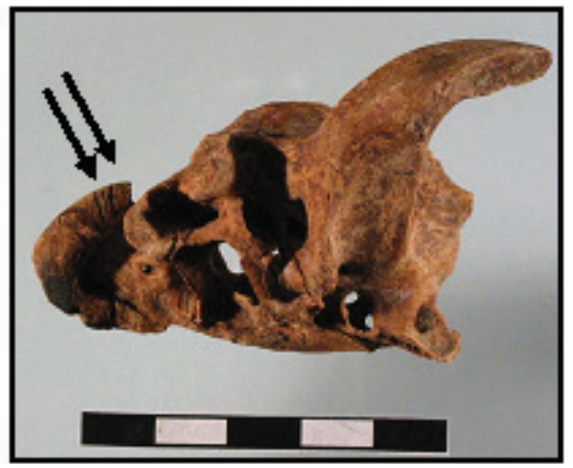

7.

Planșa I. 1. Bos taurus, proces cornular de femelă (normă nucală); 2. Bos taurus, astragal stânga (normă medial) cu urme de tăiere; 3. Capra hircus, procese cornulare (normă medială); 4. Capra hircus, proces cornular dreapta cu urme de tăiere la bază (normă medială); 5. Sus domesticus, mandibule stânga (a) şi dreapta (b şi c - normă craniană); 6. Sus domesticus, mandibule dreapta (a - normă laterală) şi stânga (b şi c - normă linguală); 7. Canis familiaris, neurocraniu (normă bazală) cu urme de tăiere și ardere; 8. Canis familiaris, neurocraniu (normă laterală) cu urme de tăiere și ardere.

2.

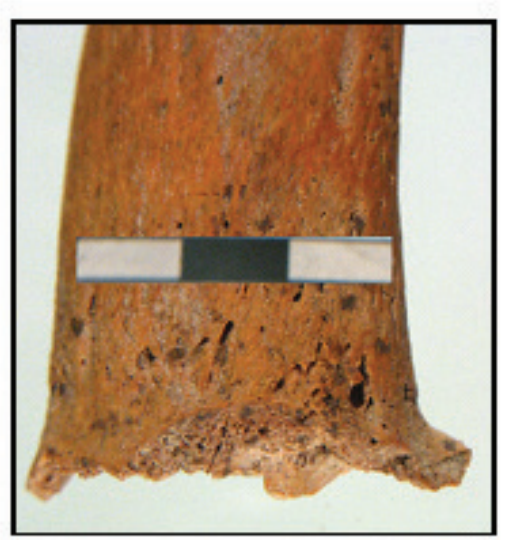

4.

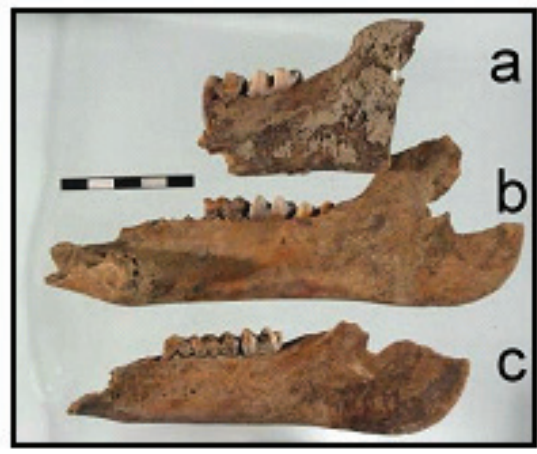

6.

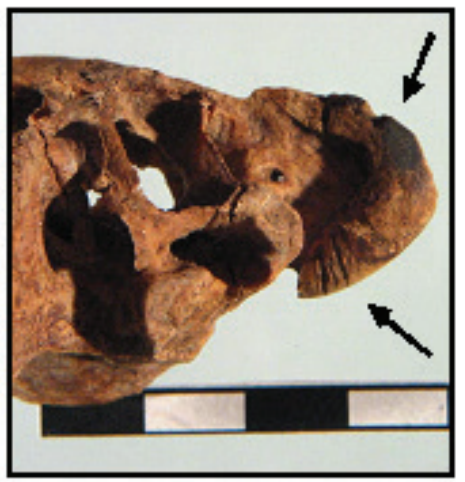

8.

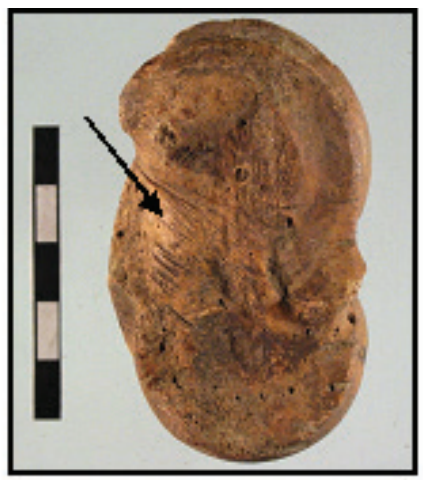

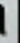

\section{b} C .

\section{.}




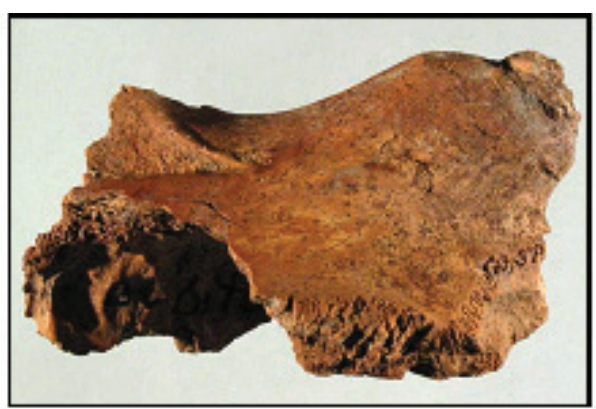

1.

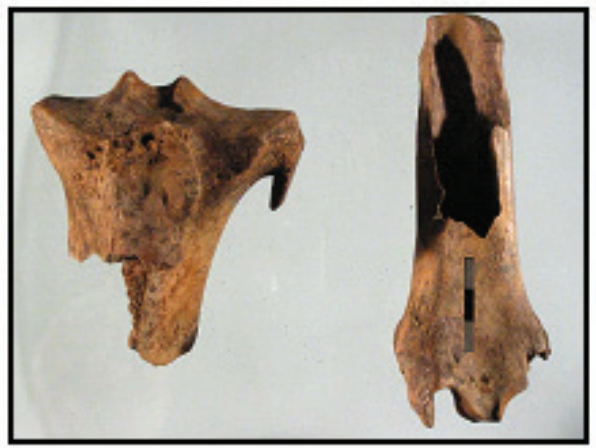

3.

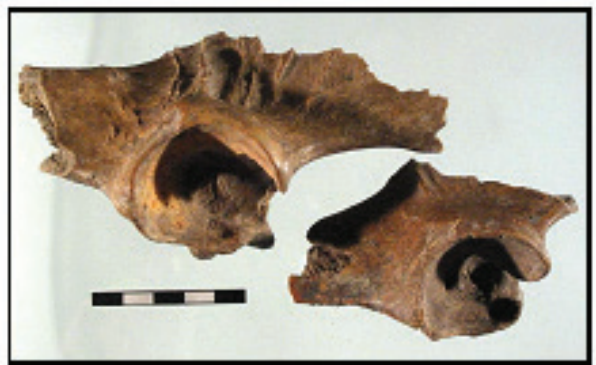

5.

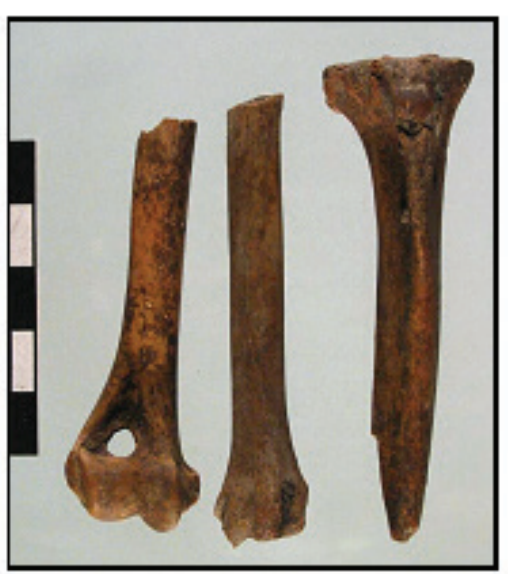

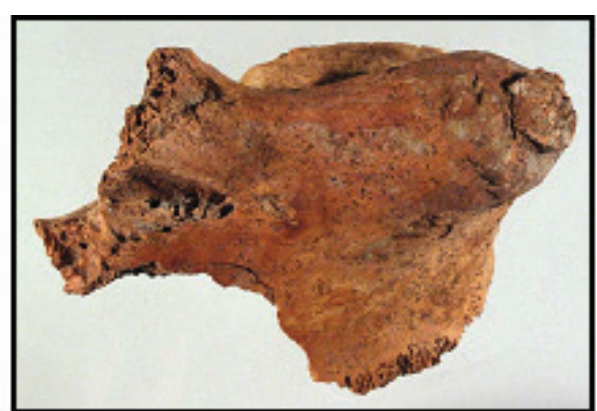

2.

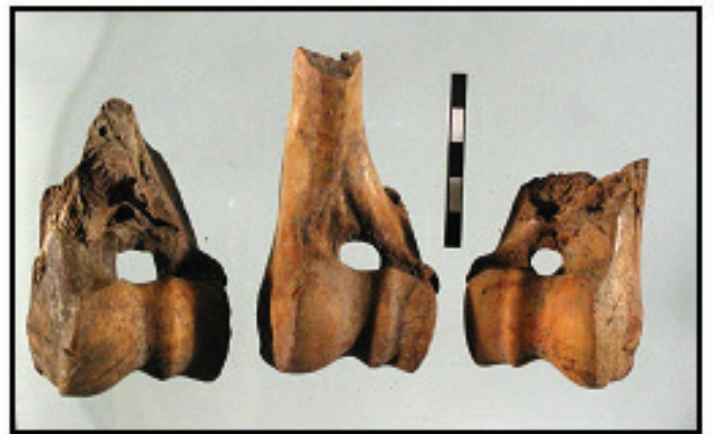

4.

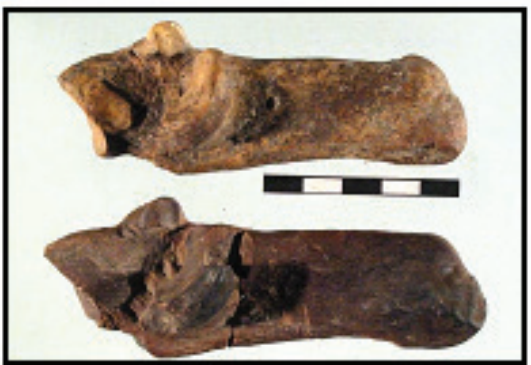

6.

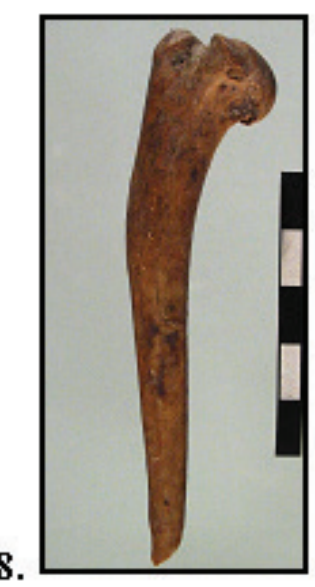

Planșa II. 1. Cervus elaphus, neurocraniu cu urme de tăiere la baza cornului (normă medială); 2. Cervus elaphus, neurocraniu cu urme de tăiere la baza cornului (normă dorsală); 3. Cervus elaphus, tibie proximală (în stânga) şi tibie distală (în dreapta) (normă dorsală); 4. Sus scrofa, humerusuri distale (normă cranială); 5. Sus scrofa, coxale stânga (normă laterală); 6. Sus scrofa, calcanee dreapta (normă medială); 7. Vulpes vulpes, humerus (stânga), radius (mijloc), tibie (dreapta) (normă dorsală); 8. Felis silvestris, humerus proximal (normă medială). 
1.
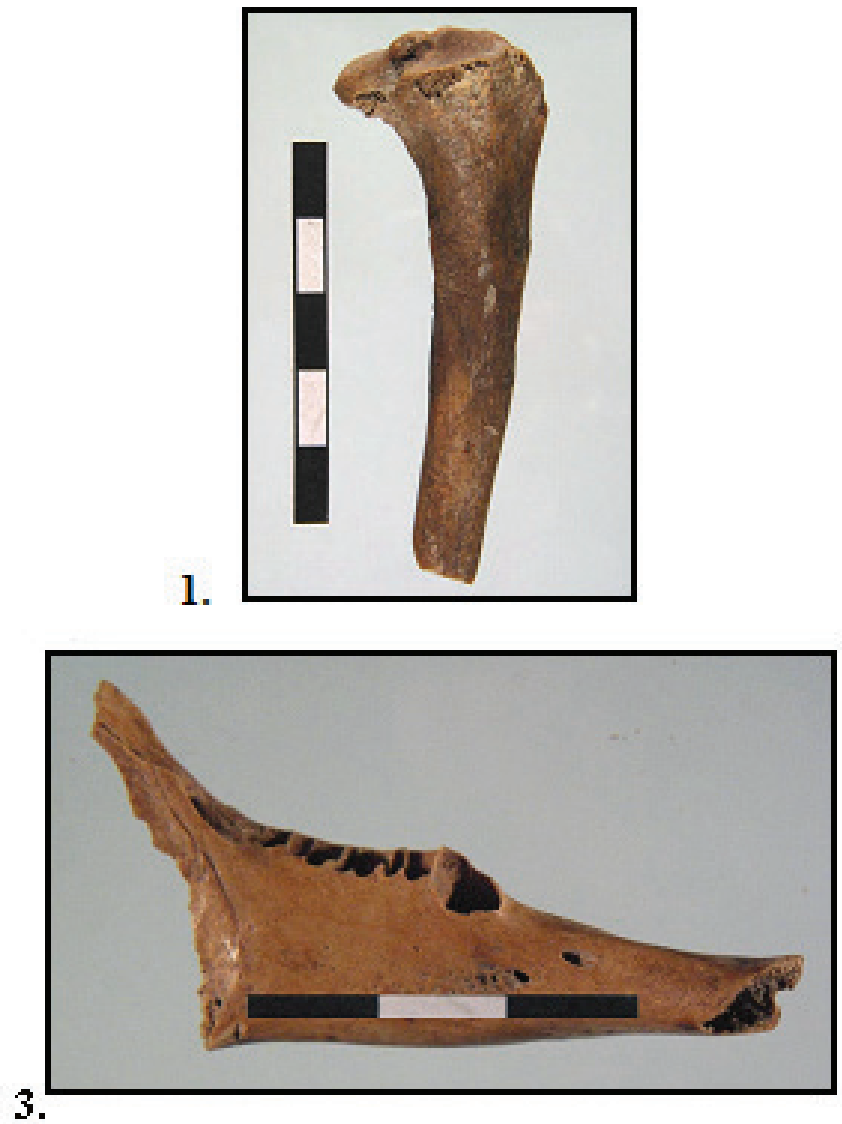

2.

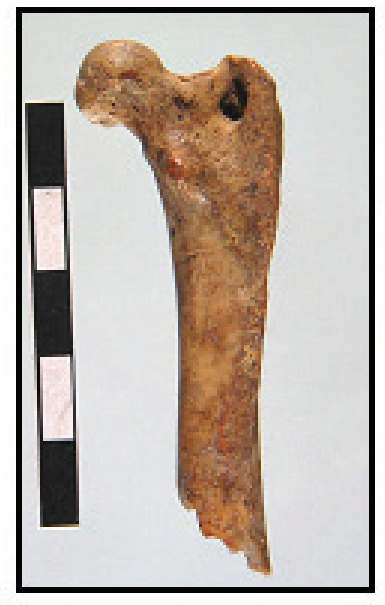

4.

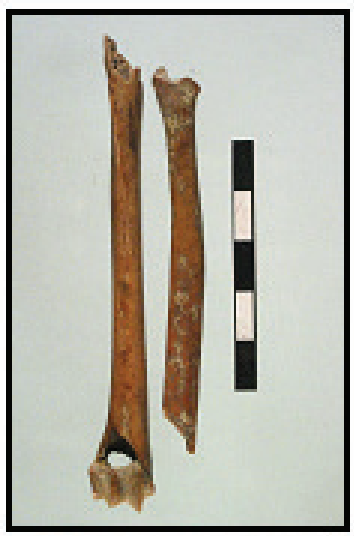

Planșa III. 1. Meles meles, tibie proximală stânga (normă medială); 2. Lutra lutra, femur dreapta cu urme de descărnare (normă caudală); 3. Lepus europaeus, mandibulă dreapta (normă laterală); 4. Lepus europaeus, humerus distal (stânga) şi radius proximal (dreapta) (normă dorsală). 